

\title{
Psychosocial Competencies and Risky Behaviours in Peru
}

\author{
Marta Favara and Alan Sánchez
}

(C) Young Lives 2016

ISBN 978-1-909403-70-3

A catalogue record for this publication is available from the British Library. All rights reserved. Reproduction, copy, transmission, or translation of any part of this publication may be made only under the following conditions:

- with the prior permission of the publisher; or

- with a licence from the Copyright Licensing Agency Ltd.,

90 Tottenham Court Road, London W1P 9HE, UK, or from another national licensing agency; or

- under the terms set out below.

This publication is copyright, but may be reproduced by any method without fee for teaching or non-profit purposes, but not for resale. Formal permission is required for all such uses, but normally will be granted immediately. For copying in any other circumstances, or for re-use in other publications, or for translation or adaptation, prior written permission must be obtained from the publisher and a fee may be payable.

Young Lives, Oxford Department of International Development (ODID), University of Oxford, Queen Elizabeth House, 3 Mansfield Road, Oxford OX1 3TB, UK 


\section{Contents}

Summary $\quad 4$

The Authors $\quad 4$

Acknowledgements 4

1. Introduction 5

2. Literature review $\quad 8$

2.1 Theoretical strands of the literature on risk behaviours 8

2.2 Soft skills as predictors of risky behaviours: evidence from policy and research

4

4

4

5

8

8

3. Patterns of risky behaviours in Peru 10

4. Data, definitions and descriptive statistics 11

4.1 Data 11

4.2 Risky behaviours: definition and statistics using Young Lives data 12

4.3 Predictors of risky behaviours 14

5. Empirical strategy 16

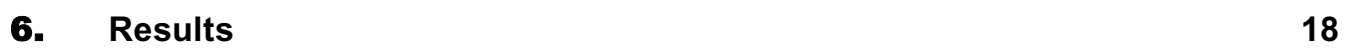

6.1 Fixed-effects estimates $\quad 20$

7. Conclusions and discussion $\quad 21$

References $\quad 24$

$\begin{array}{ll}\text { Appendix } & 40\end{array}$ 


\section{Summary}

We use a unique longitudinal dataset from Peru to investigate the relationship between psychosocial competencies related to the concepts of self-esteem, self-efficacy and aspirations, and a number of risky behaviours at a crucial period of transition between adolescence and early adulthood. First, we document a high prevalence of risky behaviours, with one in two individuals engaging in at least one risky activity by the age of 19 , and a dramatic increase between the ages of 15 and 19. Second, we find a pronounced pro-male bias and some differences according to area of residence, particularly in the consumption of alcohol, which is more prevalent in urban areas. Third, we find a negative correlation (robust to a number of specifications) between early self-esteem and later risky behaviours. Further, aspiring to higher education at the age of 15 is found to be correlated with a lower probability of drinking and of engaging in criminal behaviours at the age of 19. Similarly, such aspirations protect girls from risky sexual behaviours.

\section{The Authors}

Marta Favara is a Research Officer at Young Lives, and an IZA Research Affiliate. Her research is on applied micro-economics, and behavioural and labour economics, in middle- and lowincome countries. Her current research interests focus on understanding which factors, aside from the purely economic ones, affect individuals' behaviours and choices. Before joining Young Lives, she worked at the World Bank (Poverty and Education Global Practices in Latin America and Western Africa).

Alan Sánchez is a Research Associate at GRADE (the Grupo de Análisis para el Desarrollo) in Lima, and the Principal Investigator for Young Lives Peru. He is also a part-time lecturer at Universidad de Piura in Lima, Peru. His research has focused on the study of the short-term and long-term consequences of early-life shocks; skills formation; and impact evaluation of social programmes. Before joining GRADE, he worked at the Economic Research Division of the Banco Central de Reserva del Peru (Central Bank of Peru).

\section{Acknowledgements}

We are grateful to Santiago Cueto for his detailed and helpful feedback. A special thanks to Grace Chang and Maria Gracia Rodriguez for excellent research assistance. We are also grateful to colleagues at Young Lives for insightful discussions in this research area. Readers are invited to send comments to marta.favara@qeh.ox.ac.uk and asanchez@grade.org.pe.

\footnotetext{
About Young Lives

Young Lives is an international study of childhood poverty, following the lives of 12,000 children in 4 countries (Ethiopia, India, Peru and Vietnam) over 15 years. www.younglives.org.uk

Young Lives is funded by UK aid from the Department for International Development (DFID) and co-funded by Irish Aid from 2014 to 2016. This report is part of a stream of research on 'Changing women's lives in social context: economic growth, cultural norms and the dynamics of gender inequality in Ethiopia, India, Peru and Vietnam', funded by the William and Flora Hewlett Foundation.

The views expressed are those of the authors. They are not necessarily those of, or endorsed by, Young Lives, the University of Oxford, DFID or the William and Flora Hewlett Foundation.
} 


\section{Introduction}

Risky behaviours are associated with health problems, low productivity, and more generally with a decline in individual and collective well-being in the short, medium, and long run (see, for example, Parkes et al. 2010). The study of the determinants of risky and criminal activities is informed mainly by sociological and psychological literature establishing the link between cognitive skills, psychosocial competencies and risky behaviours (Caspi et al. 1994; Agnew et al. 2002; Pratt and Cullen 2000). ${ }^{1}$

The economic literature on crime and risky behaviours primarily adopts an opportunity-cost framework. People choose to commit a crime or to engage in risky behaviours if their expected utility from engaging in that behaviour is greater than the expected utility from their alternative options (for example, labour-market opportunities). Within this framework, bettereducated people or people with better cognitive abilities are less likely to be involved in risky behaviours (Travis and Hindelang 1977; Lochner and Moretti 2004). However, these models do not acknowledge the role of psychosocial competencies.

More recently, economists have developed an interest in studying the role of soft skills (or non-cognitive skills) as predictors of economic outcomes, such as educational attainment, health status, and labour-market outcomes (see, for example, Borghans et al. 2008, Heckman et al. 2006, Cobb-Clark and Tan 2011, Dohmen et al. 2010, Chiteji 2010, and Jaeger et al. 2010). Nevertheless, few economic papers analyse the link between soft skills and risky behaviours.

The aim of this study is to gain a better understanding of the link between psychosocial competencies and risky behaviours at a crucial period of transition between adolescence and early adulthood. Specifically, our analysis has three objectives. First, to document the prevalence of risky behaviours in the context of Peru, and the heterogeneity of these outcomes in terms of gender and area of location. Second, to test the hypothesis that dimensions related to the concepts of self-esteem, self-efficacy and aspirations have an impact on the occurrence of risky behaviours during adolescence. Third, to test the robustness of this association by applying statistical methods which allow us to control for unobservable cofounders.

For this analysis we exploit the longitudinal nature of the Young Lives data, a unique individual-level panel following a cohort of about 700 children in Peru over four rounds of data collection which took place between 2002 and 2013. The Young Lives data cover a critical phase of the life-cycle for human capital and skills accumulation, following the same children between the ages of 8 and 19. Information on a number of risky behaviours is collected at the ages of 15 and 19, which makes the Young Lives data particularly suitable for this analysis. Furthermore, rich information at both household and individual levels is collected, including children's cognitive and psychosocial competencies, school history,

1 There is an on-going debate, and little agreement, on how to refer to those skills which represent 'patterns of thought, feelings and behaviour' (Borghans et al. 2008) and which encompass those traits that are not directly represented by cognitive skills or by formal conceptual understanding. The current list includes such terms as behavioural skills, soft skills, personality traits, non-cognitive skills or abilities, character, life-skills, and socio-emotional and psychosocial skills or competencies. In this paper, we use the term 'soft skills' and 'psychosocial competencies' interchangeably. 
parental and children's aspirations, and aspirations for education. ${ }^{2}$ Drawing on the data available, we define indicators to measure the prevalence of (i) smoking behaviours; (ii) drinking behaviours; (iii) drinking and violence (engaging in violent or risky activities when drunk); (iv) consumption of illegal drugs; (v) criminal behaviours; (vi) possession of weapons; (vii) unprotected sexual activity; and (viii) total number of risky and criminal behaviours.

Evidence of psychosocial competencies as a predictor of criminality and delinquency invites questions about the ability to prevent risky behaviours by shaping those skills. Furthermore, while the most 'sensitive' (productive) periods for investment in both cognitive skills and psychosocial competencies occur earlier in people's lives, soft skills during adolescence are more malleable than cognitive skills (Knudsen et al. 2006; Cunha and Heckman 2008; Cunha et al. 2010; Cunha and Heckman 2007; Carneiro and Heckman 2003). Of course, the differential plasticity of different age-related skills has important implications for the design of effective policies.

Three recent studies have considered the determinants of risky behaviours at age 15 in Peru, using the first three rounds of Young Lives data: Cueto et al. 2011, Crookston et al. 2014, and Lavado et al. 2015. The study by Cueto et al. (2011) highlights the importance of parentchild relations and peer effects in predicting smoking habits and unprotected sexual activity at early ages. Crookston et al. (2014) document the association between child victimisation at school and subsequent risky behaviours. Finally, the study by Lavado et al. (2015) looks at the relationship between cognitive and non-cognitive skills, consumption of cigarettes and alcohol, and early sexual initiation. Overall, their results suggest a negative relation between risky behaviours and cognitive and non-cognitive skills.

However, the evidence that these studies can provide is limited, for two reasons. First, there is a low prevalence of risky behaviours observed at age 15 , which authors try to compensate for by using extremely inclusive definitions, particularly in the way that smoking and drinking are defined. Second, there is an endogenous relationship between child characteristics and risky-behaviour outcomes. There are reasons to believe that psychosocial competencies and the outcomes of interest are jointly determined. Therefore, the main challenge is to assess whether the effect of poor psychological resources on the probability in engaging in risky behaviours is due to potential endogeneity bias - either through reverse causality or through uncontrolled confounding variables.

In this analysis we try to overcome both challenges. First (the question of low prevalence), we show that in most cases the frequency of risky behaviours has increased considerably between the ages of 15 and 19, which makes the empirical study more viable. Furthermore, the use of the last round of data allows us to broaden the scope of risky behaviours observed (at age 19, individuals were asked to report criminal behaviours in addition to reports of the other risky behaviours collected in previous rounds). Second (potential endogeneity bias), although this paper does not claim any causal relation, we exploit the fact that the data were collected over multiple periods to implement strategies which minimise both sources of endogeneity. To deal with reverse causality, we use lagged values of the psychosocial variables of interest, measured three years before the realisation of the risky behaviours. To deal with omitted variable bias, we estimate a child fixed-effects model, which purges bias due to unobservables that are constant over time.

2 It is important to note that information about cognitive and psychosocial competencies is collected for all children, regardless of their school-enrolment status, which avoids any selection problem commonly arising from the use of school-based tests. 
These are our main findings. First, we find that the prevalence of risky behaviours is evident and increases significantly over time: by age 15 , two out of 10 individuals had engaged in at least one risky behaviour, whereas by age 19 one out of two had done so. By age 19, the prevalence of smoking and drinking is 19 and 34 per cent respectively; 13 per cent had consumed illegal drugs, 27 per cent had had unprotected sex, and 19 per cent had engaged in criminal behaviours.

Second, with the exception of unprotected sexual activity, there is a notorious pro-male bias in the prevalence of most of these behaviours. There are also some differences in terms of area of location, particularly in the consumption of alcohol, which is more prevalent in urban areas.

Third, and perhaps most importantly, we find a negative correlation between psychosocial competencies and risky behaviours. Keeping everything else constant, an improvement of one standard deviation in self-esteem at the age of 15 is associated with a reduction of 6,7 and 8 percentage points respectively in the probability of smoking, drinking and engaging in violent behaviours while drinking at the age of 19 . It is also associated with a reduction in the prevalence of criminal behaviours and in the possession of a weapon, by 14 and 5 percentage points respectively. No similar correlation is found with self-efficacy. These results are robust to a large set of controls at the child and household levels and to community characteristics that are fixed over time. Moreover, child fixed-effects estimates show that these associations persist after controlling for time-invariant unobservable characteristics. We note further that early self-esteem, measured at the age of 12 , is already a predictor of later drugs consumption, unprotected sex, criminal behaviours and the number of risky behaviours in which the adolescents engage at the age of 19.

Finally, we find that aspiring to higher education at the age of 15 reduces the probability of drinking and engaging in criminal behaviours at the age of 19 by 14 and 25 percentage points respectively. Furthermore, while on average girls are more at risk of unprotected sex, girls aspiring to higher education are less likely to have unprotected sex. Nevertheless, once we control for unobservable individual characteristics, the correlation between aspirations and risky behaviours is no longer significant.

The remainder of the paper is structured as follows: Section 2 discusses the different strands of theoretical literature on risky behaviours and reviews the empirical economic literature on the determinants of risky behaviours; Section 3 documents recent patterns in risky behaviours in Peru, using the Demographic and Health Survey; Section 4 describes the data and the core predictors of risky behaviours used in the present analyses, together with some statistics on risky behaviours using the Young Lives data; Section 5 discusses the empirical strategy and specifications adopted; and finally Section 6 and 7 report and discuss our findings. 


\section{Literature review}

\subsection{Theoretical strands of the literature on risk behaviours}

In this section we review the three theoretical strands of the literature on risk behaviours: first the traditional economic literature; then developmental-psychology literature; and finally the behavioural-economics literature. Most of the literature and empirical evidence on risky behaviours applies to developed countries and the adult population.

The traditional economic approach to youth risk-taking is, as mentioned above, a utilitymaximisation/opportunity-cost approach. Forward-looking individuals pursue a certain activity if the expected benefits of it exceed the expected costs. One example of a model using this approach is the 'rational addition model' developed by Becker and Murphy (1988).

Developmental psychology, although not necessarily in contrast to the traditional economic approach, considers a wider variety of factors determining young people's decisions to engage in risky behaviours. As Fischhoff (1992) effectively summarises, according to developmental psychologists, (risk-related) decision-making depends on three groups of factors: how people 'think' about the world, i.e. their capacity for thinking through problems, examining the alternatives available and evaluating their implications ('cognitive' development); how people 'feel' about the world ('affective' development); and the roles that others play in people's choices ('social' development).

Finally, behavioural economists bring the two approaches together and enrich economic models with a number of dimensions suggested by developmental psychologists (O'Donoghue and Rabin 2001). We highlight here the most relevant features for youth decision making.

The first one is related to the way in which short-run benefits and long-run costs are modelled. Empirical evidence suggests that young people are excessively myopic with respect to the future and therefore are more likely to have inconsistent preferences over time (O'Donoghue and Rabin 2001; Gruber and Koszegi 2000). More specifically, they have a tendency to have a discount rate that is higher in the short run than in the long run. Young people respond to uncertainty about the future by reducing the importance of the future, an effect known as 'hyperbolic discounting'.

The second feature is related to young people's tendency to introduce projection bias (O'Donoghue and Rabin 2001; Loewenstein et al. 2000). They have limited capacity to appreciate the extent to which their preferences may adapt over time, and they tend to project their current preferences inappropriately on to their future tastes. For this reason, random changes to their current states affect their long-run decision making.

The third feature is related to the young people's attitude to risk (O'Donoghue and Rabin 2001; Gruber 2001). Young people tend to be less risk-averse than older people, which is consistent with the myopia and hyperbolic-discounting features. Moreover, risky decisions are made in uncertain environments, and for many risky activities the cost is one-time and permanent. Uncertainty and one-time cost with longer-term implications might increase risktaking behaviours, and a mistake made in the past becomes permanent in its consequences. 


\subsection{Soft skills as predictors of risky behaviours: evidence from policy and research}

Many studies in the economic literature find evidence of a contemporaneous correlation between different risky behaviours (DiNardo and Lemieux 1992; Model 1993; Chaloupka and Laixuthai 1997; Farrelly et al. 2001; Dee 1999; Wiefferink et al. 2006; DuRant et al. 1999). Such evidence supports the 'bad seed' hypothesis, as described by Gruber (2001). The hypothesis is that there is a certain segment of the youth population that is predisposed towards risky activities, while others are not. In that case, policies targeting the segment of the population at risk should work effectively. An alternative hypothesis in the psychological literature is that there is a certain degree of risk that youths have a tendency to take ('conservation of risk' hypothesis). Reducing risky activity in one area would have a substitution effect by increasing risky activities in another.

To date, most intervention programmes have been targeting specific groups of the population considered to be at risk, mainly by targeting single risk behaviours. Most recently, there are examples of interventions taking a broader approach and targeting more than one risky behaviour at a time. More specifically, they aim to address some underlying determinants of risky behaviours which are believed to protect young people from, or predispose them to, distinct risky behaviours. Therefore a better understanding of which childhood traits predict risky behaviours is crucial from a policy perspective.

Empirical evidence suggests that interventions focusing on improving cognitive skills or aimed at improving soft skills are effective in reducing risky behaviours. An example of an intervention aimed at improving opportunities for children from poor backgrounds is the wellknown Perry Preschool Program, an intervention targeting a sample of African-American children aged 3-4 living in poverty and assessed to be at high risk of school failure. Although the literature originally focused on the cognitive impact of the intervention, long-term effects have in fact been more persistent in non-cognitive areas. Heckman et al. (2010) and Conti et al. (2012) show that Perry significantly enhanced adult outcomes, including education, employment, earnings, marriage, participation in healthy behaviours, and reduced participation in crime, teenage pregnancy, and welfare dependency later in life. Interestingly, although the programme initially boosted the IQs of participants, this effect soon faded. A persistent effect has been found in the form of improvements in personality skills (for example, it reduces aggressive, anti-social and rule-breaking behaviours). On the other hand, Hill et al. (2011) show that several interventions which focused on personality rather than solely on cognitive skills were effective in reducing delinquency and traits related to delinquency.

Few economic papers analyse the role of personality traits and non-cognitive skills in criminal activities, or risky behaviours more generally. Heckman et al. (2006) find that self-esteem and locus of control measured during adolescence are as powerful as cognitive abilities in predicting adult earnings. Moreover, they find that personality factors for men affect the probability of daily smoking more than cognitive factors do, and the opposite is true for women. Similarly, Cunha et al. (2010) show that personality traits are relatively more important in predicting criminal activity than cognitive traits are. Further, Conti and Heckman (2010) suggest that personality and health status measured during adolescence explain more than 50 per cent of the difference in terms of poor health, depression and obesity at age 30. For males, personality traits and health endowments are more predictive than cognitive skills, while for women they are equally predictive. 


\section{Patterns of risky behaviours in Peru}

Information about the prevalence of risky behaviours among young people in Peru is scarce. The National Committee for a Life Without Drugs (DEVIDA) provides estimates for the consumption of alcohol, cigarettes and illegal drugs among the population from 12 to 65 years in Lima City -the capital of the country, where about one-third of the population lives (DEVIDA 2013). According to DEVIDA, 12 per cent of individuals consume cigarettes in the $12-18$ age group, and the figure increases to 32 per cent in the 19-29 age group. The prevalence of alcohol consumption increases from 32 per cent at ages 12-18 to 69 per cent at ages 19-29. In terms of gender differentials, there is a clear pro-male bias in the consumption of both cigarettes and alcohol. In the case of illegal drugs, the prevalence is much lower: around 3 per cent in both age groups. The main drug consumed is marijuana. In this case, there is also a pro-male bias in consumption.

In terms of the prevalence of unprotected sex, this information can be obtained from the Peru Demographic and Health Survey, which contains nationally representative information for women of reproductive age, from 14 to 50 years old. We use this survey to construct indicators of sexual behaviours (ever had a sexual relationship, and age of first sexual intercourse) and unprotected sex for females. These results are reported in Table 1. To resemble the age-periods observed in the Young Lives study, results are reported separately for adolescents aged 15 to 17 , and young females aged 18 to 19 . We find that the proportion of females who had ever had sexual intercourse increases from 18 per cent at ages 15-17 to 53 per cent at ages 18-19. On the other hand, the proportion of females who engaged in unprotected sex (i.e. without a condom) during their most recent act of intercourse is similar for both age groups: approximately two out of ten.

Although the above is useful as a first diagnosis, the data available present some limitations and concerns in terms of comparability with Young Lives data. First, there is no available information about the frequency of the consumption of cigarettes and alcohol, so it is not possible to determine whether the prevalence of cigarettes and alcohol consumption observed in Lima City corresponds to habitual consumption, as opposed to occasional consumption. Second, the information related to the consumption of legal and illegal drugs is not collected at the national level and, at best, is informative about urban areas only. Third, the information about risky sexual behaviours is available only for females. Fourth, all the information available was obtained from face-to-face interviews. Results are therefore likely to be biased, particularly in the case of illegal drugs consumption. Finally, there is no information available related to the prevalence of criminal behaviours.

In the next section we present the Young Lives data for Peru and show how they can be used to enable a better understanding of the prevalence and the predictors of risky behaviours among young people, as well as their determinants. 


\section{Data, definitions and descriptive statistics}

\subsection{Data}

The data used in this paper come from the Young Lives Panel Survey, a longitudinal study which follows 12,000 children in Ethiopia, India (Andhra Pradesh and Telangana), Peru and Vietnam over 15 years. The sample in each country consists of two cohorts: an Older Cohort, born in 1994/95, and a Younger Cohort, born in 2001/03. The first wave of the study was in 2002 (Round 1), which was then followed by three subsequent rounds in 2006 (Round 2), 2009 (Round 3), and 2013 (Round 4). The attrition rate across all four rounds is relatively low compared with other longitudinal studies, particularly for Peru, where the attrition rate is 6.3 per cent for the Younger Cohort and 10.3 per cent for the Older Cohort.

The Young Lives sample for Peru gathers information concerning approximately 700 Older Cohort children and 2,000 Younger Cohort children, with an over-sampling of poor areas. The original sample was spread over 20 clusters in different geographical regions. ${ }^{3}$ More specifically, the 20 clusters were randomly selected from the universe of districts in 2002, excluding the wealthiest 5 per cent. Each district was awarded a probability of being selected in proportion to its population size. Then, within each selected district, an area was randomly selected, and families with children aged 6 to 18 months and 7 to 8 years were selected to be part of the Younger Cohort and Older Cohort respectively. Although Young Lives is not intended to be nationally representative, it is worth highlighting that, because of the sampling procedure used, the Young Lives sample for Peru has been found to optimally reflect the diversity of children and families in Peru, excluding the wealthiest 5 per cent. ${ }^{4}$ In the present analysis, we use data for the Older Cohort at the ages of 8 years in 2002, 15 years in 2009, and 19 in 2013. For this cohort, data on risky behaviours were collected in both Round 3 and Round 4 (ages 15 and 19).

A key challenge involved in the collection of risky-behaviours data is the danger of substantial under-reporting, due to cultural factors as well as legal reasons (in the case of the consumption of illegal drugs). This problem is particularly acute in face-to-face interviews. Although Young Lives administers face-to-face interviews for both the child or young person and his or her family, the information on risky behaviours comes from a self-administered questionnaire which includes a set of questions about alcohol, cigarettes and drugs consumption, together with questions about sexual behaviours, contraceptive use and knowledge about sexual and reproductive health. This questionnaire was applied in Rounds 3 and 4 , following a meticulous protocol with the aim of minimising under-reporting.

The protocol of the self-administered questionnaire, which is typically applied at the end of the visit, is as follows. The interviewer explains to the child or young person that he or she will be asked a number of questions about aspects that might be considered sensitive, such as consumption of alcohol, cigarettes and even drugs, together with sexual behaviours,

3 These include three clusters in the department of Lima, and 17 in Amazonas, Ancash, Apurimac, Arequipa, Ayacucho, Cajamarca, Huanuco, Junin, La Libertad, Piura, Puno, San Martin, and Tumbes.

4 For more details of the sampling design, see Escobal and Flores 2008. 
contraceptive use and knowledge about sexual and reproductive health. The informant is told that he or she is free to choose to complete the questionnaire or not, and free to leave questions blank if wished. Then the interviewer states that all the answers will remain confidential and that, once the informant has completed the questionnaire, the paper will be put in a sealed envelope and the questionnaire and its envelope will be identified by a code, not by a name. Once the interviewer has given this information, the child is asked whether he or she wants to complete the questionnaire. If the informant agrees, he or she is left alone for 15 minutes. Finally, once the questionnaire is completed, it will be sealed in an envelope with the code that corresponds to the child.

The aim of the protocol previously described is to assure the child that his or her answers will remain confidential (as indeed is the case). Following this procedure, the percentage of children who decided to answer the questionnaire was very high. In Round 4, only 3.8 per cent of the sample refused to complete the self-administered questionnaire. Of those who agreed to answer, 1.6 per cent left all the self-administered questions blank. Among those who decided to go on, the proportion of missing answers is relatively small, especially for questions related to smoking, drinking, possession of a weapon and criminal behaviours (1.3 per cent of missing answers related to the consumption of cigarettes; 0.5 per cent to alcohol consumption; up to 1.0 per cent to alcohol consumption and engagement in risky activities; 0.5 per cent to possession of a weapon; and up to 1.5 per cent to questions related to criminal behaviours). The proportion of missing answers is slightly larger for sexual relations (4.0 per cent for questions related to use of condoms during last sexual intercourse) and consumption of illegal drugs (up to 5.8 per cent). Although there may be some level of underreporting hidden in the answers that were left blank, the fact that a small proportion of children answered in this way leads us to believe that this is unlikely to produce a significant bias in our results, particularly because we do capture a high proportion of adolescents engaged in risky behaviours, as will be shown in the following sections.

\subsection{Risky behaviours: definition and statistics using Young Lives data}

In this paper we investigate a number of risky behaviours for which information is available at the ages of both 15 and 19. More specifically, we look at smoking, alcohol and drugs consumption, unprotected sex, and weapons possession. More details on the survey questions administered are available in Table 2. In Tables A.1 and A.2 in the Appendix we report their distribution by age, gender, and rural/urban location.

On the basis of these survey questions, we define seven risky-behaviours indicators for the empirical analysis. In the remaining part of this section, we define them and we highlight a number of stylised patterns emerging from our data. In Table 3 we report the prevalence of risky behaviours at the ages of 15 and 19 , by gender and by rural/urban location, alongside tests for statistical significance.

Smoking participation ('smoking' variable) is defined as a dummy variable equal to 1 for those individuals who reported smoking cigarettes at least once per month. At the age of 19, about 19 per cent of our sample report themselves to be smoking (Table 3). On average they smoke their first cigarette at the age of 16 . Most of them (89 per cent) report smoking only one cigarette per day, or less (see Table A.1 in the Appendix).

With respect to alcohol consumption, there is growing public concern about how much alcohol young people are drinking in their teenage years. According to our data, drinking is 
the activity with the highest prevalence at the ages of both 15 and 19. At the age of 15 about 65 per cent of the sample report that they never drink alcohol; among those who do, most of them drink exclusively on special occasions or very sporadically. By the age of 19 the number of young people reporting that they drink increases tremendously, although most of them do not drink on a regular basis. ${ }^{5}$

Although the proportion of 19-year-olds who drink regularly is quite low (fewer than 1 per cent drink alcohol on a daily basis, and 3 per cent at least once per week), alcohol consumption increases tremendously between 15 and 19, as does the number of times they admit to alcohol-related abuse. Excessive alcohol consumption not only puts their own health at risk, but also makes them more likely to get involved in anti-social behaviours.

We defined two variables for excess alcohol consumption: the 'drinking' variable equal to 1 for those adolescents who got drunk at least once in their life (and 0 otherwise), and the 'drinking and violence' variable equal to 1 for those who engaged in risky behaviours (either having sex, or engaging in a fight, or feeling sick or drunk) while drinking. By the age of 19 , about 34 per cent of the sample report having been drunk, and 40 per cent report having engaged in risky behaviours while drinking (Table 3).

With respect to sexual behaviours, about 67 per cent of our sample had had sex by the age of 19 , on average having the first sexual relation at the age of 16 (see Table A.1 in the Appendix). We define a variable to capture those young people at risk of sexually transmitted diseases (STDs). ${ }^{6}$ The 'unprotected sex' variable is equal to 1 for those who did not use a condom in the most recent sexual relationship (including also those who used other birthcontrol methods or emergency contraception) and 0 for those who had protected sex (using condoms) or never had sex.

For drugs consumption we define an indicator to identify those who had ever tried any drugs: about 13 per cent by the age of 19 .

Similarly, the dummy variable for weapon possession is equal to 1 for those who during the last 30 days had carried a weapon at least once.

Overall, considering the incidence of risky behaviours by age, we notice that risky behaviours increase significantly between the age of 15 and the age of 19, corresponding to the transition from childhood to adolescence (Table 3). It is worth noting that by the age of 19 male engagement in risky behaviours is about two to three times greater than that of females in terms of smoking, drinking and taking drugs, and criminal behaviours. There is also an urban-rural difference in relation to drinking, where adolescents living in urban areas drink more ( 9 per cent by the age of 15 and 37 per cent by the age of 19) relative to those in rural areas ( 5 per cent by the age of 15 and 24 per cent by the age of 19) and by the age of 19 are more likely to engage in risky behaviours while drinking.

However, not only the prevalence but also the intensity of risky behaviours increases over time. We define a variable counting the number of risky activities in which the young people have been involved by the ages of 15 and $19 .^{7}$ By the age of 15 , about 22 per cent of young

5 In other words, they could be defined as 'social drinkers'. 'Social drinking' refers to casual drinking in a social setting without necessarily intending to get drunk.

6 Unfortunately, Young Lives only collects information about the use of contraceptive methods in the last sexual relationship.

7 The intensity variable includes all the risky-behaviours variables as defined above. With respect to alcohol consumption we include the 'drinking' variable only. 
people have engaged in at least one risky behaviour. By the age of 19 , slightly more than one out of two had engaged in at least one type of risky behaviour, with a distinctive pro-male bias (65 per cent among males, 43 per cent among females). While 28 per cent of the population engaged in only one risky activity, there is an equally consistent segment of the youth population ( 28 per cent), mainly young men, which undertakes more than one of these activities.

Our data report a remarkable diffusion of risky behaviours among Peruvian adolescents, and a worrisome predisposition towards risky activities for the relevant part of them. Although our data do not provide full support to either the 'bad seed' or the 'conservation of risk' hypothesis, it is worth noting that there is evidence of a certain persistence ('recidivism') in risky behaviours. Those who engage in risky behaviours at the age of 15 are indeed more likely to engage in risky behaviours at the age of 19 . The average 'number of risky behaviours' at the age 15 is strongly correlated with the same measured four years later (standardised correlation coefficient of 0.6). Recidivism is more evident in some risky behaviours than others, particularly in drugs consumption, drinking and smoking. In fact, adolescents who consume drugs at age 15 are 64 percentage points more likely to consume drugs at age 19. Similarly, drinking (smoking) at age 15 increases the probability of smoking (drinking) at age 19 by 38 percentage points (39 percentage points).

In the next section we further characterise these young people: using a multivariate approach, we investigate who they are, their history, their past experience, their ability, their psychosocial well-being, and where they live.

\subsection{Predictors of risky behaviours}

In this section we briefly discuss the core predictors of risky behaviours. We focus exclusively on those predictors that are either time-invariant or are available in earlier rounds of the Young Lives survey.

As we discussed in the previous section, soft skills have been identified as important factors in predicting risky behaviours. In our data, we capture soft skills (or psychosocial competencies) through two indicators that have been administered in the last three rounds of the Young Lives survey: the self-esteem scale and the self-efficacy scale. In the Young Lives database, these scales are referred to as the pride index and the agency index, respectively. The former builds on the self-esteem concept presented by Rosenberg (1965) and is related to the individual's overall evaluation of his/her own worth. The latter builds on the concepts of locus of control presented by Rotter (1966) and self-efficacy put forward by Bandura (1993); it measures the child's freedom of choice and his/her agency (or power) to influence his/her own life. The full list of survey questions included to compute the two scales is reported in Table $2 .^{9}$

Another core predictor for risky behaviours is individual aspirations. There is a considerable body of economic literature investigating the role played by aspirations and subjective expectations in contraceptive choices (Delavande 2008); (sexual) risky behaviour (De Paula et al. 2013; Shapira 2013); and non-marital child-bearing choices (Wolfe et al. 2007). As Dalton et al. (2015) argue, how far people aspire depends on their own beliefs about what

8 Table 2 documents the indicators used in the analysis, and their definitions or procedure of computation.

9 It is worth noting that the correlation between these scales is 0.25 . This suggests that the scales capture different dimensions of the child. 
they can achieve with effort, i.e. their own expectations. People would not aspire to an outcome that is perceived as inaccessible. Consistently with the 'opportunity cost' argument in the risky-behaviour literature, if an outcome is perceived as inaccessible, people might believe that they have little to lose by engaging in a risky behaviour.

However, given the endogenous nature of aspirations, the empirical distinction between aspirations and expectations is hard to achieve in a non-experimental setting. Therefore, the measure of aspirations considered in this study reflects a combination of aspirations and beliefs about the likelihood of achieving the hoped-for outcomes. Young Lives collects information about educational aspirations by asking the child the following question: 'Imagine you had no constraints and could study for as long as you liked, or go back to school if you have already left. What level of formal education would you like to complete?'. In this study, we define a dummy variable equal to 1 for individuals with high aspirations, i.e. for those children who aspire to go to university, and 0 otherwise.

As noted in previous sections, patterns of risky behaviours may vary by gender and may change significantly during adolescence. While there is consistent evidence in the literature of a higher prevalence of risky behaviours among boys, the age pattern is more complex. In fact, while younger teens tend to be both more impatient and more subject to peer pressure (Lewis 1981), which could make them more prone to risk taking than older teens, there are at least three factors which might counterbalance this: biology, income and law (Gruber 2001). Indeed, some risky activities (for example, sexual intercourse) become desirable with age (biology). Moreover, some illegal activities for younger teens become legal at older ages (for example, cigarette consumption is illegal under the age of 19 in Peru) (law). Finally, older teens may have more money available to finance their risky activities (income).

Related to this last point, poverty is often seen as a trigger factor for engaging in risky behaviours. In the present analysis we approximate the socio-economic status of the natal household by using the following criteria: father's and mother's education level; an indicator for the rural/urban location where the household resides; and the tercile of wealth index, a composite measure of living standards including housing quality, access to services and a consumer-durable index, as defined in Table 2.

Finally, we consider two additional sets of potential predictors of risky behaviours related to household composition and education, and cognitive skills. The first set of characteristics that we look at relates to household composition. In the light of the results of past research, we include the number of siblings and whether the informant is living with only one biological parent (broken home). ${ }^{10}$

We also control for whether the young person has an older sibling. Siblings, and in particular older siblings, might affect the behaviour of our sample child by being a role model to them and by enlarging their peer groups. There is a consistent body of literature investigating the influence of family and peers on the behaviour of disadvantaged youths. For example, Clark and Loheac (2007) use the Add Health survey to examine risky behaviour by American adolescents. They find that the consumption of tobacco, alcohol and marijuana is correlated with peer-group behaviour. The correlation is stronger for alcohol use and among young males more commonly than among young females. 
We also control for a dummy variable to identify movers, i.e. those children/families who are living in a different community from where they lived when they were 8 years old. There is some evidence of a positive association between displacement and risky behaviours. For example, Gaviria and Raphael (2001) suggest that recent movers may be more susceptible to peer-group pressure.

Finally, we look at a set of predictors relating to education. More specifically we investigate school enrolment, delayed enrolment and school achievement. School achievement, measured by either the Raven test score or the Peabody Picture Vocabulary Test (PPVT) and also by a maths test, can also be considered as a proxy of the child's cognitive skills. Notably, the two tests have been collected for all children, regardless of whether they are attending school or not. This feature of the data avoids any of the selection problems which commonly arise from the use of school-based data.

As an initial exploration of factors that might affect the probability of engaging in risky behaviours at the age of 19 , we compare the mean characteristics of the predictors listed above for adolescents 'at risk' (engaging in at least one risky behaviour by the age of 19) and adolescents 'not at risk'. All predictors are measured when the adolescent was 12 and 15 years old. These differences are presented in Table 4 alongside tests for statistical significance.

Looking first at the individual characteristics, we note that young people engaging in risky behaviours by the age of 19 are more likely to be boys and to be slightly older than those who are not at risk. Young people 'at risk' have lower self-efficacy (slightly lower self-esteem) and are less likely to aspire to university at the age of 15 . Furthermore, risky behaviours are more prevalent among young people with lower cognitive skills (performing worse in the maths test) and those who have already dropped out of school by the age of 15 .

Interestingly, risky behaviours are not necessarily a phenomenon prevalent among young people living in poverty. Indeed, young people living in poverty are as likely as young people living in less poor households to engage in risky behaviours.

Additionally, there is no difference in the prevalence of risky behaviours in rural and urban areas, and the level of parental education is the same among young people at risk and those who are not at risk. Notably, risky behaviours are more prevalent in single-parent households.

\section{Empirical strategy}

In this section we define a multivariate set-up, estimating linear probability (OLS) models. Our dependent variables are the risky behaviours as defined in the previous sections. With the exception of the intensity variable (number of risky behaviours), the dependent variable is a variable equal to 1 if the young person engages in risky behaviours at the age of 19 , and 0 otherwise.

First of all, we investigate the predictors of risky behaviours by looking at the association between risky behaviours measured at the age of 19 and psychosocial competencies measured at the age of 15 , controlling for schooling achievement and a broad set of early (or time-invariant) individual and household-level characteristics, as follows: 


$$
Y_{i j, 19}=\beta_{0}+\alpha_{i}+\beta_{1} \text { self-efficacy }_{i, 15}+\beta_{2} \text { self-esteem }_{i, 15}+X_{i, 15} \Gamma+\omega_{j}+\epsilon_{i, 19}
$$

In this model $Y_{i j, 19}$ denotes risky behaviour outcomes of individual $i$ living in the community $j$ observed at age 19; self-efficacy $y_{i, 15}$ and self-esteem ent15 $_{i, 1}$ are measured at the age of 15; $X_{i, 15}$ is a vector of pre-determined characteristics of individual $i$ recognised as potential predictors of risky behaviours. In particular, $X_{i, 15}$ includes some indicators of household socio-economic status (proxied by the wealth-index tertiles, a dummy variable for households living in rural areas, paternal and maternal education); information about family structure (the number of siblings, a dummy for single-parent household, and a dummy equal to 1 if the child has an older sibling and 0 otherwise); individual school achievement (measured by the standardised PPVT score and maths test, both taken at the age of 15); a dummy variable equal to 1 whether the young person at the age of 19 is living in the same community as when he/she was 15 years old and 0 otherwise; the sex and the age of the child at the time of the 2013/14 survey round. The term $\alpha_{i}$ reflects unobserved individual characteristics that are constant over time. Finally, $\epsilon_{i, 19}$ is an idiosyncratic error and $\omega_{i}$ is a set of community dummies to control for unobservable characteristics common at community level.

Similarly, we investigate the correlation between educational aspirations measured the age of 15 and risky behaviours at the age of 19 . According to the 'opportunity cost' argument, we would expect to find a negative correlation between aspirations and risky behaviours if the perceived cost of engaging in risky behaviours increases with aspirations. The descriptive statistics presented in Table 4 indeed show that adolescents engaging in at least one risky behaviour at the age of 19 have lower aspirations than 'not at risk' adolescents.

Given that aspirations are likely to feed into the child's self-efficacy and self-esteem, we estimate a separate model similar to the one discussed above, but including a dummy variable equal to 1 for those children who at the age of 15 aspire to complete higher education (university), and 0 otherwise:

$$
Y_{i j, 19}=\theta_{0}+\alpha_{i}+\theta_{1} \text { aspirations }_{i, 15}+X_{i, 15} \Gamma+\omega_{j}+\epsilon_{i, 19}
$$

In both equation (1) and equation (2), self-efficacy, self-esteem and aspirations are measured at the age of 15. An empirical question is whether the psychosocial competencies measured at younger ages predict later risky behaviours. Young Lives collects evidence of self-efficacy, self-esteem and aspirations at the ages of both 12 and 15 , which allows us to examine the long-term association with risky behaviours. We also report results for this longterm specification. In this case all control variables are either time-invariant or measured as early as possible (at age 8 ). In this case, the Raven score measured at age 8 is used as indicator of school achievement.

Although informative, an estimation of the risky-behaviours equations using cross-sectional data would be unbiased only under very strong assumptions about the role of unobservable variables. In the absence of plausibly exogenous variations in the regressors, their estimation raises endogeneity concerns and might lead to biased interpretations. Therefore, our intention is not to identify causal effects. Rather, the estimated parameters should be interpreted as partial correlations which may yield insights into potential drivers of risky behaviours at different ages and the channels through which such effects may be mediated. 
Further, we exploit the fact that we have repeated measures of risky behaviours, and we estimate the outcome of interest using a child fixed-effects model, as follows:

$$
\begin{aligned}
\Delta Y_{i j, 19-15}= & \beta_{1} \Delta \text { self_efficacy } y_{i, 15-12}+\beta_{2} \Delta \text { self_esteem }_{i, 15-12}+ \\
& \Delta X_{i, 15-12} \Gamma+\Delta \epsilon_{i, 19-15}
\end{aligned}
$$

and similarly,

$$
\Delta Y_{i j, 19-15}=\theta_{1} \Delta \text { aspirations }_{i, 15-12}+\Delta X_{i, 15-12} \Gamma+\Delta \epsilon_{i, 19-15}
$$

In this specification, the role of self-efficacy and self-esteem is identified by exploiting changes between ages 12 and 15 which in turn lead to changes in risky behaviours between ages 15 and 19. In doing so, we implicitly assume that the relevant coefficients are ageindependent. This strategy has the advantage that it controls for individual unobservable characteristics that are constant over time.

\section{Results}

The main results of the analysis are reported in Table 5 and Table 6 . Outcomes are measured at age 19, whereas, unless otherwise expressed, predictors are measured at age 15. Smoking, drinking, and drinking and violence are the outcomes for which the highest proportion of the variance is explained by the selected predictors, with an R-squared of around 20 per cent. In contrast, for drug consumption, risky sex and criminal-related outcomes between 10 and 13 per cent of the variance is explained.

The four most consistent predictors of risky and criminal behaviours are gender, age, selfesteem and whether the individual comes from a single-parent household. The fact that there are differential patterns by gender and age was already evident in the descriptive statistics. The probability of smoking, drinking and engaging in drinking and violence increases respectively by 21,22 and 24 percentage points for males compared with females. Similarly, males are 13 and 11 percentage points more likely than females to consume drugs and engage in criminal behaviours respectively. Although the average age is 19 , many individuals were aged 18 at the time of the interview. We find that advancing from the age of 18 to the age of 19 increases the likelihood of smoking, drinking and drinking and violence by around 10 percentage points in all cases, whereas the prevalence of drug consumption increases by 5 percentage points.

Beyond the role of gender and age, our main finding is related to the association between self-esteem and risky and criminal behaviours. Given that the estimation controls for demographic and socio-economic characteristics, as well as for schooling achievement and time-invariant community characteristics, among other aspects, the estimated parameter can be interpreted as a robust association. Keeping other factors constant, a 1 standard-deviation increase in self-esteem at age 15 reduces the likelihood of engaging in smoking, drinking and drinking and violence by 6, 7 and 9 percentage points (respectively); it also reduces the likelihood of criminal behaviours and carrying a weapon by 13.8 percentage points and 3.7 percentage points. In contrast, the association with self-efficacy is not statistically significant, though it is interesting to observe that the estimated coefficients have the expected (negative) sign.

About the role of family structure, a specific dimension which plays a role is whether the individual comes from a single-parent household, which increases the likelihood of engaging 
in drinking and violence, in criminal behaviours, and in risky sex by 10, 16 and 15 percentage points respectively. In addition, the number of siblings is positively associated with criminal behaviours and with the probability of carrying a weapon.

It is interesting to observe that the role of socio-economic characteristics and schooling achievement is relevant only for certain types of outcome, and that the specific characteristics that matter depend on the nature of the risky behaviours. We find that household wealth (as measured by the wealth index) is not associated with any of the risky behaviours; however, other socio-economic dimensions such as parental education (for criminal behaviours), area of location and migration (for drinking behaviours) are. Specifically, we observe a negative association between father's education and criminal behaviours.

We also observe that living in a rural area reduces drinking by 27 percentage points, whereas having migrated between the ages of 15 and 19 increases the same probability by 17 percentage points (most of the observed migration implies moving from rural to urban areas). Finally, keeping other factors constant, we do not find a statistically significant association between schooling achievement and risky behaviours. However, there is a strong negative association between school enrolment and criminal behaviours.

From the factors previously mentioned, gender, age, self-esteem and living in a single-parent household stand out as factors that systematically predict risky and criminal behaviours. These are also the factors that predict the (overall) number of risky behaviours in which the individual has engaged.

Also, it is interesting to observe that psychosocial competencies do not play any role in predicting risky sexual behaviours. This is surprising, given that previous literature suggests self-efficacy (or self-confidence) to be one of the key factors for contraceptive use, and particularly for the use of condoms, which, particularly for girls, requires negotiating their use with the partner (see, for example, Salazar et al. 2005).

More generally, unprotected sex is the behaviour for which fewer predictors turn out to be statistically significant (only one, that of coming from a single-parent household), which suggests that other important predictors might have been neglected. Factors such as being born to a teenage mother, knowledge of sexual and reproductive health, access to contraceptive methods, age of the sexual debut, and relationship status are some of the factors commonly correlated with teenage pregnancy and motherhood (see, for example, Azevedo et al. 2001 and Ermisch and Pevalin 2003). Furthermore, being married or in a stable relationship might influence the decision to use contraceptive methods. Nevertheless, these factors have been not included in the analysis, mainly for two reasons: first, the need to preserve comparability across the different risky behaviours considered; second, the fact that some of those variables are collected in Round 4 only. ${ }^{11}$

In Table 6 we report the results for the risky-behaviours models, including educational aspirations. Keeping everything else constant, in this model we observe that aspiring to higher education reduced the likelihood of drinking and engaging in criminal behaviours by 14 and 25 percentage points respectively. Higher aspirations are also negatively correlated

11 It is important to note that by including a dummy for marital/cohabiting status and an indicator for the child's understanding of sexual reproduction the estimated coefficients for self-efficacy and self-esteem do not qualitatively change. However, the inclusion of those variables improves the statistical fit of our model, and the r-squared increases from 0.09 to 0.16. 
with the total number of risky behaviours. The role played by the other predictors (the same as in the previous model) remains very similar. One noticeable difference is that, once aspirations are controlled for, school enrolment does not predict criminal behaviours, which suggests that aspirations and school enrolment, both measured at the age of 15 , are strongly correlated.

To further explore the possible differential correlation of psychosocial competencies with risky behaviours by gender, in Tables 7 and 8 we replicate the same results, adding an interaction between male gender, self-esteem and self-efficacy, and between male gender and aspirations, respectively. The only noticeable result is that while on average girls are more at risk of unprotected sex than boys, girls aspiring to higher education are less likely to have unprotected sex. Therefore, if the relation between aspirations and risky behaviours proved to be causal, having higher educational aspirations would be likely to prevent girls engaging in unprotected sex relatively more than boys.

So far we have shown that psychosocial competencies and aspirations measured at the age of 15 predict many risky behaviours that occur at the age of 19 . An empirical question is whether this correlation is constant over time, and whether psychosocial competencies and aspirations measured earlier in life similarly predict later behaviours.

In Table 9 and Table 10 we report the estimates for the risky- behaviour model where early psychosocial competencies and aspirations are measured at the age of 12 . Analogous to previous results, early self-esteem is negatively correlated with drugs consumption, unprotected sex and criminal behaviours, and with intensity of engagement in risky behaviours more generally. Similarly, children aspiring to higher education at the age of 12 are less likely to carry weapons at the age of 19.

On the contrary, children with higher levels of self-efficacy at the age of 12 are relatively more at risk of engaging in risky behaviours. More specifically, an increase of one standard deviation in the self-efficacy indicator is correlated with an increase of 4 and 5 percentage points in relation to smoking and engaging in unprotected sex. This seems to suggest that while higher self-esteem during childhood and throughout adolescence might play a protective role against risky behaviours later on in life, self-efficacy during childhood might indeed have the opposite effect (and not a significant effect during adolescence). The reasons for this might reside in the nature of the two soft skills themselves. Self-efficacy, which reflects the individual's judgment of his or her own capacity to act and exert agency, is also intrinsically related to action and behaviour. This is where it differs from 'self-esteem', which is a more passive concept, without a necessary expression in action, and is about the individual's judgement of self-worth.

Thus, for those adolescents with pre-existing low self-efficacy, the transition to adolescence (and the risky-behaviour experimentation as part of this process of development) can be problematic.

\subsection{Fixed-effects estimates}

In order to obtain a better identification of the relationship between psychosocial competencies and the outcomes of interest, we report individual fixed effects estimates. We exploit the variation over time (between age 19 and 15) in individual risky and criminal behaviours and we estimate it as a function of a change in psychosocial competencies and in the other control variables between the ages of 12 and 15 . These results are reported in Tables 11 and 12. For this part of the analysis, the criminal-behaviours variable is dropped, 
because it is not observed at age 15 . Gender and parental education do not vary over time, and because age varies uniformly across all children between survey waves, these variables are also dropped.

In Table 11, we report the results for the individual fixed-effects estimates using self-esteem and self-efficacy as predictors of risky behaviours. The results are qualitatively similar to the ones discussed above. An increase in self-esteem is negatively correlated with the prevalence of risky behaviours over time. More specifically, one standard-deviation increase in self-esteem reduces smoking, drinking and engaging in drinking and violence by 5, 10 and 9 percentage points respectively; it does not predict the likelihood of carrying a weapon, but the point estimate is very similar ( 3 percentage points). In contrast to the results in the previous model, self-efficacy is predictive of carrying a weapon. One standard-deviation increase in self-efficacy reduces the probability of carrying a weapon by 5 percentage points. Besides this, in this set of estimations, educational achievement is found to play a more prominent role. School enrolment reduces the likelihood of drinking alcohol, drugs consumption and risky sex. A similar role is played by vocabulary and maths achievement. In addition, coming from a single-parent household, area of location, and migration remain as important predictors of risky behaviours.

In Table 12, we report the results for the individual fixed-effect model, including aspirations among the predictors. However, in this case we are not able to detect a relationship between aspirations and the outcomes of interest.

To summarise, the fixed-effects estimates show that the relationship between self-esteem and risky behaviours is very robust, whereas the relationship between self-efficacy, aspirations and risky behaviours is not. In addition, there seems to be a lot of meaningful variation over time in the control variables, which allows us to show that coming from a single-parent household, the area of location, migration and educational achievement are also important factors which play a role in the determination of risky and criminal behaviours.

\section{Conclusions and discussion}

There is a growing concern about the prevalence of risky behaviours among young people, which ultimately lead to worse outcomes later in life, including lower salaries and worse socio-economic and life outcomes. On the other hand, there is little evidence about the prevalence of these behaviours and their determinants in the context of developing countries. Our aim is to try to fill this gap, using unique individual-level panel data from Peru, following a cohort of children for over a decade between the ages of 8 and 19.

We constructed indicators to measure the prevalence of smoking and drinking; engaging in risky behaviours when drunk; consumption of illegal drugs; unprotected sex; criminal behaviours; possession of weapons; and total number of risky behaviours. While we do not claim any causal relation, the methods used allow us to deal with bias arising from reverse causality and omitted variables that are constant over time.

Our main findings can be summarised as follows. First, we find that the prevalence of risky behaviours in the Young Lives Peruvian sample is evident and increases with age: by age 15 , two out of 10 individuals had engaged in at least one risky behaviour, whereas by age 19 one out of two had done so. Although these results are not claimed to be representative of Peruvian youth, the fact that the Young Lives sample covers the diversity of the country in 
terms of living standards suggests that the prevalence of risky conduct among Peruvian youth is likely to be large.

Second, our analysis of the predictors of risky behaviours identifies a group of adolescents vulnerable to pressure to engage in risky behaviours. This is particular relevant for boys living in urban areas who have grown up in single-parent households with a high number of siblings. More specifically, there is a notorious pro-male bias in the prevalence of most of these behaviours. There are also some differences by area of location, particularly in the consumption of alcohol, which is less prevalent in rural areas.

Third, and perhaps most importantly, we find a negative correlation between early selfesteem and a number of risky behaviours, including smoking, drinking, drinking and violence, criminal behaviours, and possession of a weapon. Higher levels of self-esteem at the age of 15 considerably reduce the probability of engaging in risky behaviours at the age of 19 . The correlation found is robust to a number of specifications and, when controlled for unobservable individual characteristics, constant over time. We note further that early selfesteem, measured at the age of 12 , is already a predictor of later drugs consumption, unprotected sex, criminal behaviours and the number of risky behaviours engaged in by adolescents at the age of 19 .

Finally, while no similar link is found with self-efficacy, we find that aspiring to higher education at the age of 15 predicts a lower probability of drinking and engaging in criminal behaviours at the age of 19 by 14 and 25 percentage points respectively. Furthermore, while girls on average are more at risk of unprotected sex, girls aspiring to higher education are less likely to have unprotected sex. Nevertheless, once we control for unobservable individual characteristics, the correlation between aspirations and risky behaviours is no longer significant.

From this analysis we identify a number of drivers of risky behaviours. In particular, there is a specific group of young people who are at risk: boys living in urban areas and growing up in single-parent households. In the case of girls, they are more likely to be exposed to unprotected sex. Although these groups are identified for the Peruvian context, similar patterns are likely to be observed in countries with similar characteristics (middle-income countries with relatively high levels of poverty and low levels of secondary-school attainment).

We also observe a dramatic increase in risky behaviours between the ages of 15 and 19 , which suggests that policy interventions aiming at preventing risky behaviour should be put in place at age 15 or earlier, when risky behaviours manifest in only a small segment of the population.

Although the present analysis is not a sufficient basis on which to claim any causal relation between socio-emotional competencies and risky behaviours, it does provide some interesting hints. Our results suggest that psychosocial competencies, and self-esteem and high aspirations in particular, might play a role in reducing risky behaviours. As far as we know, this evidence is unique in the developing-countries context. Policies aimed at promoting soft skills during childhood and adolescence can play an important role as a mechanism to reduce risky and criminal activities among young people.

From a policy perspective, considering the age range analysed as well as the fact that, by age 15, most Peruvian adolescents are still attending school, we argue that it is worth exploring whether interventions designed to take place at secondary-level schools can reduce the engagement of adolescents in risky behaviours. 
In terms of more comprehensive interventions, the Ministry of Education in Peru is currently implementing an Extended School Day Programme (Jornada Escolar Completa, JEC). This initiative seeks both to extend the length of the school day and to provide better services to students at the secondary level in urban areas.

Theoretically, JEC and similar initiatives can have direct as well as indirect effects on the prevalence of risky behaviours. First of all, longer school hours mean that students spend a greater number of hours per day under adult supervision, which limits the possibility of engaging in risky behaviours. Further, inasmuch as extended school days have been found to improve academic achievement in middle-income countries (Bellei 2009; Aguero and Beleche 2013), this type of programme can be expected to reduce the prevalence of risky behaviours by increasing the opportunity cost of engaging in them (indirect effect).

Finally, as part of the JEC programme in Peru a full-time psychologist has been incorporated into every JEC school to improve students' psychosocial well-being. Our results suggest that improving psychological competencies might be an additional mechanism through which the JEC might reduce the prevalence of risky behaviours.

Similar programmes are currently being implemented in the Latin American region (in Chile, Colombia, Mexico and Uruguay). In the case of Chile, a nationwide educational reform extended the school day from 32 to 39 hours per week. Berthelon and Kruger (2011) find that teens living in municipalities with greater access to full-day high schools had a lower probability of becoming mothers during their adolescence. An increase of 20 percentage points in the municipal share of full-day high schools reduces the probability of motherhood in adolescence by 3.3 per cent.

This encouraging finding from Chile suggests that it is worthwhile exploring the potential effects of this type of reform on risky behaviours. Further research on JEC in Peru and its effect on risky behaviours will be done, using the next round of data. 


\section{References}

Agnew, R., T. Brezina, J.P. Wright and F.T. Cullen (2002) 'Strain, Personality Traits and Delinquency: Extending General Strain Theory', Criminology 40.1: 43-72.

Aguero, J.M. and T. Beleche (2013) 'Test-Mex: Estimating the Effects of School Year Length on Student Performance in Mexico', Journal of Development Economics 103 (C): 353-361.

Azevedo, J.P., M. Favara, S.E. Haddock, L.F. Lopez-Calva, M. Muller and E. Perova (2001) Teenage Pregnancy and Opportunities in Latin America and the Caribbean on Early Child Bearing, Poverty and Economic Achievement, World Bank Group.

Bandura, A. (1993) 'Perceived Self-efficacy in Cognitive Development and Functioning', Educational Psychologist 28.2: 117-148.

Becker, G.S. and K.M. Murphy (1988) 'A Theory of Rational Addiction', The Journal of Political Economy: 675-700.

Bellei, C. (2009) 'Does Lengthening the School Day Increase Students' Academic Achievement? Results from a Natural Experiment in Chile', Economics of Education Review 28.5: 629-640.

Berthelon, M. and D. Kruger (2011) 'Risky Behavior Among Youth: Incapacitation Effects of School on Adolescent Motherhood and Crime in Chile', Journal of Public Economics 95.1-2.

Borghans, L., A.L. Duckworth, J.J. Heckman and B. ter Weel (2008) 'The Economics and Psychology of Personality Traits', Journal of Human Resources 43.4: 972-1059.

Carneiro, P.M. and J.J. Heckman (2003) Human Capital Policy, IZA discussion paper, Bonn: Institute for the Study of Labor.

Caspi, A., T.E. Moffitt, P.A. Silva, M. Stouthamer-Loeber, R.F. Krueger and P.S. Schmutte (1994) 'Are Some People Crime-prone? Replications of the Personality-Crime Relationship Across Countries, Genders, Races and Methods', Criminology 32.2: 163-196.

Chaloupka, F.J. and A. Laixuthai (1997) 'Do Youths Substitute Alcohol and Marijuana? Some Econometric Evidence', Eastern Economic Journal 23.3: 253-276.

Chiteji, N. (2010) 'Time Preference, Non-cognitive Skills and Well-being Across the Life Course: Do Non-cognitive Skills Encourage Healthy Behavior?', American Economic Review 100.2: 200-204.

Clark, A.E. and Y. Loheac (2007) "'It Wasn't Me, It Was Them!" Social Influence in Risky Behavior by Adolescents', Journal of Health Economics 26.4: 763-784.

Cobb-Clark, D.A. and M. Tan (2011) 'Non-cognitive Skills, Occupational Attainment and Relative Wages', Labour Economics 18.1: 1-13.

Conti, G. and J.J. Heckman (2010) 'Understanding the Early Origins of the Education-Health Gradient', Perspectives on Psychological Science 5.5: 585- 605.

Conti, G., J.J. Heckman, S.H. Moon and R. Pinto (2012) 'Long-term Health Effects of Early Childhood interventions', unpublished manuscript.

Crookston, B.T., R.M. Merrill, S. Hedges, C. Lister, J.H. West and P.C. Hall (2014) 'Victimization of Peruvian Adolescents and Health Risk Behaviors: Young Lives Cohort', BMC Public Health 14.1: 1-7. 
Cueto, S., V. Saldarriaga and I.G. Munoz (2011) 'Conductas de Riesgo Entre Adolescentes Peruanos: Un Enfoque Longitudinal', Salud, Interculturalidad y Comportamiento de Riesgo Lima: GRADE, 119-58.

Cunha, F. and J.J. Heckman (2007) 'The Technology of Skill Formation', American Economic Review 97.2: 31-47.

Cunha, F. and J.J. Heckman (2008) 'Formulating, Identifying and Estimating the Technology of Cognitive and Non-cognitive Skill Formation', Journal of Human Resources 43.4: 738-782.

Cunha, F., J.J. Heckman and S.M. Schennach (2010) 'Estimating the Technology of Cognitive and Non-cognitive Skill Formation', Econometrica 78.3: 883-931.

Dalton, P.S., S. Ghosal and A. Mani (2015) 'Poverty and Aspirations Failure', The Economic Journal.

De Paula, A., G. Shapira and P.E. Todd (2013) 'How Beliefs about HIV Status Affect Risky Behaviours: Evidence from Malawi', Journal of Applied Econometrics 29.6: 944-964.

Dee, T. (1999) 'The Complementarity of Teen Smoking and Drinking', Journal of Health Economics 18.6 769-793.

Delavande, A. (2008) 'Pill, Patch or Shot? Subjective Eexpectations and Birth Control Choice', International Economic Review 49.3: 999-1042.

DEVIDA (2013) Comisión Nacional para el Desarrollo y Vida sin Drogas - IV Estudio Nacional Prevención y Consumo de Drogas en Estudiantes de Secundaria 2012 [National Commission for Development and Life without Drugs - 4th National Study on the Prevention and Consumption of Drugs among Secondary School Students 2012], Lima: DEVIDA.

DiNardo, J. and T. Lemieux (1992) Alcohol, Marijuana and American Youth: The Unintended Effects of Government Regulation, Working Paper 4212, National Bureau of Economic Research.

Dohmen, T., A. Falk, D. Huffman and U. Sunde (2010) 'Are Risk Aversion and Impatience Related to Cognitive Ability?', American Economic Review 100.3: 1238-60.

DuRant, R., J. Smith, S. Kreiter and D. Krowchuk (1999) 'The Relationship Between Early Age of Onset of Initial Substance Use and Engaging in Multiple Health Risk Behaviours Among Young Adolescents', Archives of Pediatrics \& Adolescent Medicine 153.3: 286-291.

Ermisch, J. and D.J. Pevalin (2003) Who Has a Child as a Teenager?, ISER Working Paper Series 30, University of Essex, Institute for Social and Economic Research.

Escobal, J. and E. Flores (2008) 'An Assessment of the Young Lives Sampling Approach in Peru', Oxford: Young Lives Technical Note 3.

Farrelly, M.C., J.W. Bray, G.A. Zarkin and B.W. Wendling (2001) 'The Joint Demand for Cigarettes and Marijuana: Evidence from the National Household Surveys on Drug Abuse', Journal of Health Economics 20.1: 51-68.

Fischhoff, B. (1992) Risk Taking: A Developmental Perspective, John Wiley \& Sons.

Gaviria, A. and S. Raphael (2001) 'School-based Peer Effects and Juvenile Behavior', Review of Economics and Statistics 83.2: 257-268.

Gruber, J. (2001) Risky Behavior Among Youths: An Economic Analysis, University of Chicago Press. 
Gruber, J. and B. Koszegi (2000) Is Addiction Rational? Theory and Evidence, National Bureau of Economic Research.

Heckman, J., J. Stixrud and S. Urzua (2006) The Effects of Cognitive and Non-cognitive Abilities on Labor Market Outcomes and Social Behavior, National Bureau of Economic Research, Working Paper No. 12006.

Heckman, J.J., S.H. Moon, R. Pinto, P.A. Sayelyev and A. Yavitz (2010) Analyzing Social Experiments as Implemented: A Reexamination of the Evidence from the Highscope Perry Preschool Program, Working Paper 16238, National Bureau of Economic Research.

Hill, P.L., B.W. Roberts, J.T. Grogger, J. Guryan and K. Sixkiller (2011) Decreasing Delinquency, Criminal Behavior and Recidivism by Intervening on Psychological Factors other than Cognitive Ability: A Review of the Intervention Literature, Working Paper 16698, National Bureau of Economic Research.

Jaeger, D., T. Dohmen, A. Falk, D. Human, U. Sunde and H. Bonin (2010) 'Direct Evidence on Risk Attitudes and Migration', The Review of Economics and Statistics 92.3: 684-689.

Knudsen, E.I., J.J. Heckman, J.L. Cameron and J.P. Shonkoff (2006) 'Economic, Neurobiological and Behavioral Perspectives on Building America's Future Workforce', Proceedings of the National Academy of Sciences 103.27: 10155-10162.

Lavado, P., C. Aragón and M. Gonzales (2015) 'Cuál es la Relación entre las Habilidades Cognitivas y no Cognitivas y la Adopción de Comportamientos de Riesgo? Un Estudio para el Peru', Apuntes: Revista de Ciencias Sociales 42 (76).

Lewis, C.C. (1981) 'How Adolescents Approach Decisions: Changes over Grades Seven to Twelve and Policy Implications', Child Development 52: 538-44.

Lochner, L. and E. Moretti (2004) 'The Effect of Education on Crime: Evidence from Prison Inmates, Arrests and Self-reports', American Economic Review 94.1: 155-189.

Loewenstein, G., T. O'Donoghue and M. Rabin (2000) Projection Bias in Predicting Future Utility, UC Berkeley Economics Working Paper E00-284.

Lundberg, S. and R.D. Plotnick (1990) 'Effects of State Welfare, Abortion and Family Planning Policies on Premarital Childbearing among White Adolescents', Family Planning Perspectives, 246-275.

Model, K.E. (1993) 'The Effect of Marijuana Decriminalization on Hospital Emergency Room Drug Episodes: 1975-1978', Journal of the American Statistical Association 88.423: 737747.

O'Donoghue, T. and M. Rabin (2001) 'Risky Behavior among Youths: Some Issues from Behavioral Economics', in Gruber (2001).

Parkes, A., D. Wight, M. Henderson and P. West (2010) 'Does Early Sexual Debut Reduce Teenagers' Participation in Tertiary Education? Evidence from the Share Longitudinal Study', Journal of Adolescence 33.5: 741-754.

Pratt, T.C. and F.T. Cullen (2000) 'The Empirical Status of Gottfredson and Hirschi's General Theory of Crime: A Meta-analysis', Criminology 38.3: 931-964.

Rosenberg, M. (1965) Society and the Adolescent Self-image, Princeton, NJ: Princeton University Press. 
Rotter, J.B. (1966) 'Generalized Expectancies for Internal Versus External Control of Rreinforcement', Psychological Monographs: General and Applied 80.1: 1-28.

Salazar, L.F., R. A. Crosby, R.J. DiClemente, G.M. Wingood, C.M. Les-cano, L.K. Brown, K. Harrington and S. Davies (2005) 'Self-esteem and Theoretical Mediators of Safer Sex Among African American Female Adolescents: Implications for Sexual Risk Reduction Interventions', Health Educational Behaviors 32.413.

Shapira, G. (2013) 'How Subjective Beliefs about HIV Infection Affect Life-cycle Fertility: Evidence from Rural Malawi', Policy Research Working Paper WPS 6343, Washington DC: World Bank.

Travis, H. and M. J. Hindelang (1977) 'Intelligence and Delinquency: A Revisionist Review', American Sociological Review 42.4: 571-587.

Wiefferink, Carin H., L. Peters, F. Hoekstra, G.T. Dam, G.J. Buijs and T.M.G.W. Paulussen (2006) 'Clustering of Health-related Behaviors and their Determinants: Possible Consequences for School Health Interventions', Prevention Science 7.2: 127-149.

Wolfe, B., R. Haveman, K. Pence and J. A. Schwabish (2007) 'Do Youth Nonmarital Childbearing Choices Reflect Income and Relationship Expectations?', Journal of Population Economics 20.1: 73-100. 
Table 1. Sexual behaviours and unprotected sex among young women in Peru

\begin{tabular}{|l|c|c|c|c|}
\hline \multirow{2}{*}{} & \multicolumn{2}{|c|}{ Age 15-17 } & \multicolumn{2}{c|}{ Age 18-19 } \\
\cline { 2 - 5 } & Mean & $\mathbf{n}$ & Mean & $\mathbf{n}$ \\
\hline Ever had sex (in \%) & 18.0 & 2800 & 53.0 & 1580 \\
\hline Age at first sexual intercourse (in years) & 15.0 & 563 & 16.5 & 873 \\
\hline Used condom at last intercourse (in \%) & 24.0 & 500 & 22.0 & 764 \\
\hline
\end{tabular}

Note: Peru Demographic and Health Survey 2014. Results are nationally representative.

Table 2. Definitions of variables

\begin{tabular}{|l|l} 
Variable & Description
\end{tabular}

Risky Behaviours

Smoking Dummy variable equal to 1 if she/he is 'smoking at least once a month' (or more frequently), and 0 otherwise. The survey question used is the following: 'How often do you smoke cigarettes now?'.

Drinking Dummy variable equal to 1 if she/he has been drunk at least once in his/her life, and 0 otherwise. The survey question used is the following: 'Have you ever been drunk from too much alcohol?'.

Drinking \& Violence Dummy variable equal to 1 if she/he engaged in risky behaviours (got into fights/caused trouble, felt sick or fell over, had sex) while drinking and 0 otherwise (including also those who never drank alcohol before). The survey questions used are the following: 'During the past 12 months, how many of these things happened to you because you've been drinking alcohol?' and 'During your life, have you ever been drunk from alcohol while having sex?'.

Drugs Consumption Dummy variable equal to 1 if she/he has ever consumed any of the drugs listed before, 0 otherwise: 'Have you ever tried any of the following drugs?' i.e. inhalants (terokal, gasoline, etc), marijuana, coca paste, cocaine, ecstasy, methamphetamines, hallucinogens (san pedro, ayahuasca, etc.), other drugs (crack, heroin, opium, ketamine, hashish, etc.).

Unprotected Sex Dummy variable equal to 1 if she/he did not use condoms in the last sexual relationship (or she/he used other birth-control methods or emergency contraception) and 0 for those who used a condom, or never had sex.

The survey questions used are the following:

'The last time you had sex, what did you do to prevent getting pregnant or a disease?'

We used a condom

Drank infusion or mate

Used after morning pill

Used injections to prevent getting pregnant

I don't know if used any method

We did not use any method

Other method

Criminal Behaviour An index measuring the intensity of criminal behaviour, defined by the sum of the
following dummy variables: whether the YL child has carried a weapon in the last following dummy variables: whether the YL child has carried a weapon in the last 30 days, ever been arrested by the police or taken into custody for an illegal or delinquent offence, ever been a member of a gang, or ever sentenced to spend time in a corrections institution such as a jail/prison/youth institution (juvenile hall, reform school, training school).

Carrying a Weapon Dummy variable equal to 1 if she/he carried a weapon during the last 30 days and 0 otherwise. The survey question used is the following: 'During the last 30 days, on how many days did you carry a weapon such as a knife, machete, or gun to be able to protect yourself?'

No. of Risky

An index created to measure the intensity of risky behaviour and equal to the sum of all

Behaviours the dummy variables defined above (smoking, alcohol and drugs consumption, carrying weapons and having unprotected sex). 
Table 2. Definitions of variables continued

Variable

Child's Educational

Aspirations

Psychosocial

Competencies

Self-efficacy Index

Self-esteem Index

\section{Description}

'Imagine you had no constraints and could study for as long as you liked, or go back to school if you have already left. What level of formal education would you like to complete?' Child's educational aspirations are collected at the age of 12,15 , and 18 . We define a dummy variable equal to 1 for those children with high aspirations (aspiring to university) and 0 otherwise.

This is the procedure adopted to compute the self-efficacy and self-esteem indicators:

(i) All relevant questions are recoded to be positive outcomes, (ii) relevant questions are all normalised to z-scores (subtract mean and divide by SD) and then (iii) an average of the relevant z-scores is taken across the non-missing values of the questions. All the questions are on Likert-type scales going from 1 to 4 in Round 2 (R2) and from 1 to 5 in Round 3 (R3). The questions differ a little from round to round as specified below.

If I try hard, I can improve my situation/life.

Other people in my family make all the decisions about how I spend my time.

I like to make plans for my future studies and work.

If I study hard at school, I will be rewarded by a better job in future.

I have no choice about the work I do - I must work.

I feel proud to show my friends or other visitors where I live.

I am ashamed of my clothes.

I feel proud of the job my [caregiver/household head] does.

I am often embarrassed because I do not have the right books, pencils, and other equipment for school.

I am proud of my achievements at school.

I am ashamed of my shoes.

I am worried that I don't have the correct uniform.

I am proud of the work I have to do.

I feel my clothing is right for all occasions.

Other Controls

Gender

Age

Dummy variable equal to 1 for boys and 0 for girls

Age in years

Residency - rural

Dummy variable equal to 1 if the child's household resides in rural areas and 0 otherwise

Migration

A dummy variable equal to 1 if he/she migrated between age 15 and 19 and 0 if at age 19 she/he still lives in the same community as at age 19

Wealth Index

A composite measure of living standards. The variable takes values between 0 and 1 , such that a larger value reflects a wealthier household. The wealth index is the simple average of three sub-indexes: a housing-quality index (quality of floor, wall, roof, and number of rooms per capita), an access-to-services index (access to drinking water, electricity, sanitation, and type of fuel used for cooking) and a consumer-durables index (TV, radio, fridge, microwave, computer, etc.). In the analysis we use the wealth index segmented in tertiles: bottom, middle, and top tertiles.

Parents' education Father's and mother's education, segmented into three categories for none or primary education (less than grade 8), secondary education (grade 10) and higher education (above grade 10) as their highest level of education completed

Single parent Dummy variable equal to 0 if she/he is living with both biological parents, and 1 if he/she is living with only one biological parent, the biological parent and his/her partner, or is an orphan

Child has older

siblings

A dummy equal to 1 if she/he has older siblings

Number of siblings

Number of siblings

Delayed enrolment Dummy variable which indicates 1 if the $\mathrm{YL}$ child has ever delayed school enrolment and 0 if not

Raven's test score (z- Total number of correct responses in the Raven test, standardised by round score)

PPVT (z-score)

Standardised score for the Peabody Picture Vocabulary Test by rounds

Maths (z-score)

Standardised score for the maths test by rounds

Enrolment

Dummy variable which indicates 1 if the $Y L$ child is enrolled in school or not 
Table 3. Risky behaviours by gender and rural/urban at age 15 and 19

\begin{tabular}{|c|c|c|c|c|c|c|c|}
\hline \multirow[t]{2}{*}{ Age 15} & \multirow[t]{2}{*}{ Total } & \multicolumn{2}{|c|}{ Mean } & \multirow{2}{*}{$\begin{array}{c}\text { p-value } \\
\text { t-test }\end{array}$} & \multicolumn{2}{|c|}{ Mean } & \multirow{2}{*}{$\begin{array}{c}\text { p-value t- } \\
\text { test }\end{array}$} \\
\hline & & Urban & Rural & & Female & Male & \\
\hline Smoking & 0.06 & 0.06 & 0.07 & 0.797 & 0.04 & 0.09 & 0.023 \\
\hline Drinking & 0.08 & 0.09 & 0.05 & 0.085 & 0.09 & 0.07 & 0.472 \\
\hline Drinking \& Violence & 0.12 & 0.13 & 0.10 & 0.288 & 0.12 & 0.12 & 0.973 \\
\hline Drugs Consumption & 0.02 & 0.03 & 0.00 & 0.041 & 0.02 & 0.03 & 0.260 \\
\hline Unprotected Sex & 0.06 & 0.06 & 0.05 & 0.712 & 0.05 & 0.06 & 0.625 \\
\hline Carrying a Weapon & 0.07 & 0.06 & 0.10 & 0.158 & 0.06 & 0.08 & 0.436 \\
\hline No. of Risky Behaviours: 0 & 0.78 & 0.78 & 0.80 & 0.514 & 0.81 & 0.76 & 0.214 \\
\hline No. of Risky Behaviours: 1 & 0.16 & 0.17 & 0.15 & 0.621 & 0.15 & 0.18 & 0.409 \\
\hline No. of Risky Behaviours: 2 & 0.03 & 0.03 & 0.02 & 0.628 & 0.03 & 0.03 & 0.829 \\
\hline No. of Risky Behaviours: 3 & 0.02 & 0.02 & 0.02 & 0.976 & 0.02 & 0.03 & 0.260 \\
\hline Observations & 524 & 391 & 133 & & 259 & 265 & \\
\hline \multirow[t]{2}{*}{ Age 19} & \multirow[t]{2}{*}{ Total } & \multicolumn{2}{|c|}{ Mean } & $p$-value & \multicolumn{2}{|c|}{ Mean } & p-value t- \\
\hline & & Urban & Rural & & Female & Male & \\
\hline Smoking & 0.19 & 0.20 & 0.16 & 0.350 & 0.08 & 0.29 & 0.000 \\
\hline Drinking & 0.34 & 0.37 & 0.24 & 0.012 & 0.22 & 0.45 & 0.000 \\
\hline Drinking \& Violence & 0.40 & 0.43 & 0.30 & 0.016 & 0.27 & 0.52 & 0.000 \\
\hline Drugs Consumption & 0.13 & 0.13 & 0.14 & 0.631 & 0.07 & 0.18 & 0.000 \\
\hline Unprotected Sex & 0.27 & 0.28 & 0.25 & 0.554 & 0.30 & 0.25 & 0.280 \\
\hline Carrying a Weapon & 0.05 & 0.04 & 0.08 & 0.106 & 0.05 & 0.05 & 0.930 \\
\hline Criminal behaviour & 0.19 & 0.18 & 0.22 & 0.474 & 0.13 & 0.24 & 0.027 \\
\hline No. of Risky Behaviours: 0 & 0.45 & 0.44 & 0.49 & 0.319 & 0.57 & 0.35 & 0.000 \\
\hline No. of Risky Behaviours: 1 & 0.27 & 0.27 & 0.26 & 0.815 & 0.22 & 0.31 & 0.040 \\
\hline No. of Risky Behaviours: 2 & 0.16 & 0.16 & 0.14 & 0.588 & 0.15 & 0.16 & 0.795 \\
\hline No. of Risky Behaviours: 3 & 0.12 & 0.13 & 0.11 & 0.556 & 0.05 & 0.18 & 0.000 \\
\hline Observations & 471 & 359 & 112 & & 220 & 251 & \\
\hline
\end{tabular}


Table 4. Descriptive statistics

\begin{tabular}{|c|c|c|c|c|c|c|c|}
\hline & \multicolumn{2}{|c|}{ Total } & \multicolumn{2}{|c|}{ Not at risk } & \multicolumn{2}{|c|}{ At risk } & \multirow{2}{*}{$\frac{\text { t-test }}{p \text {-value }}$} \\
\hline & Mean & $\begin{array}{l}\text { Std. } \\
\text { Dev. }\end{array}$ & Mean & $\begin{array}{l}\text { Std. } \\
\text { Dev. }\end{array}$ & Mean & $\begin{array}{l}\text { Std. } \\
\text { Dev. }\end{array}$ & \\
\hline Child is male & 0.53 & 0.499 & 0.41 & 0.493 & 0.63 & 0.483 & 0.000 \\
\hline Age in Round 4 & 18.41 & 0.549 & 18.35 & 0.544 & 18.45 & 0.550 & 0.064 \\
\hline $\begin{array}{l}\text { Father's education: primary school/none } \\
\text { N/None }\end{array}$ & 0.31 & 0.462 & 0.32 & 0.468 & 0.30 & 0.458 & 0.584 \\
\hline Father's education: secondary school & 0.47 & 0.500 & 0.44 & 0.497 & 0.49 & 0.501 & 0.230 \\
\hline Father's education: higher education & 0.20 & 0.403 & 0.22 & 0.416 & 0.19 & 0.392 & 0.385 \\
\hline Mother's education: primary school/none & 0.34 & 0.473 & 0.33 & 0.470 & 0.35 & 0.477 & 0.616 \\
\hline Mother's education: secondary school & 0.42 & 0.493 & 0.40 & 0.490 & 0.43 & 0.496 & 0.429 \\
\hline Mother's education: higher education & 0.15 & 0.362 & 0.19 & 0.388 & 0.13 & 0.338 & 0.116 \\
\hline \multicolumn{8}{|l|}{ Characteristics at the age of 15} \\
\hline Type site: rural & 0.22 & 0.415 & 0.24 & 0.426 & 0.21 & 0.407 & 0.477 \\
\hline Migrated between 15 and 19 & 0.07 & 0.256 & 0.07 & 0.249 & 0.07 & 0.261 & 0.757 \\
\hline First tercile of wealth & 0.32 & 0.469 & 0.31 & 0.464 & 0.34 & 0.473 & 0.572 \\
\hline Second tercile of wealth & 0.34 & 0.473 & 0.34 & 0.475 & 0.33 & 0.472 & 0.863 \\
\hline Third tercile of wealth & 0.34 & 0.474 & 0.35 & 0.478 & 0.33 & 0.472 & 0.699 \\
\hline Single parent, age 15 & 0.24 & 0.425 & 0.19 & 0.392 & 0.27 & 0.447 & 0.030 \\
\hline Child has older siblings & 0.34 & 0.476 & 0.34 & 0.475 & 0.35 & 0.477 & 0.858 \\
\hline Number of siblings & 1.96 & 1.270 & 2.00 & 1.288 & 1.93 & 1.257 & 0.533 \\
\hline Self-efficacy & 0.02 & 0.519 & 0.08 & 0.529 & -0.03 & 0.506 & 0.023 \\
\hline Self-esteem & 0.01 & 0.599 & 0.05 & 0.603 & -0.02 & 0.596 & 0.236 \\
\hline Child aspirations & 0.93 & 0.259 & 0.95 & 0.213 & 0.91 & 0.291 & 0.058 \\
\hline Mother's aspirations & 0.94 & 0.244 & 0.95 & 0.213 & 0.92 & 0.267 & 0.185 \\
\hline Child is enrolled & 0.94 & 0.229 & 0.97 & 0.179 & 0.93 & 0.261 & 0.057 \\
\hline PPVT (standardised) & -0.01 & 1.008 & 0.04 & 1.021 & -0.05 & 0.999 & 0.353 \\
\hline Maths (standardised) & 0.00 & 1.004 & 0.09 & 1.064 & -0.07 & 0.947 & 0.093 \\
\hline Observations & & 471 & & 212 & & 259 & \\
\hline \multicolumn{8}{|l|}{ Characteristics at the age of 12} \\
\hline Child started school late & 0.13 & 0.338 & 0.13 & 0.334 & 0.14 & 0.343 & 0.790 \\
\hline Migrated between ages 7 and 15 & 0.24 & 0.427 & 0.23 & 0.421 & 0.25 & 0.433 & 0.581 \\
\hline Self-efficacy & 0.02 & 0.506 & 0.05 & 0.450 & -0.01 & 0.546 & 0.195 \\
\hline Self-esteem & 0.04 & 0.667 & 0.07 & 0.647 & 0.01 & 0.683 & 0.270 \\
\hline Child aspirations & 0.93 & 0.260 & 0.94 & 0.241 & 0.92 & 0.275 & 0.378 \\
\hline Mother's aspirations & 0.95 & 0.212 & 0.95 & 0.224 & 0.96 & 0.203 & 0.600 \\
\hline Raven (standardised) & 0.02 & 0.997 & 0.06 & 1.058 & -0.01 & 0.946 & 0.485 \\
\hline Observations & & 509 & & 228 & & 281 & \\
\hline
\end{tabular}


Table 5. $\quad$ Predictors of risky behaviours at age 19 controlling for psychosocial competencies and other characteristics at age 15

\begin{tabular}{|c|c|c|c|c|c|c|c|c|}
\hline & Smoking & Drinking & $\begin{array}{c}\text { Drinking \& } \\
\text { violence }\end{array}$ & $\begin{array}{c}\text { Drugs } \\
\text { consumption }\end{array}$ & $\begin{array}{l}\text { Unprotected } \\
\text { sex }\end{array}$ & $\begin{array}{c}\text { Criminal } \\
\text { beh. }\end{array}$ & $\begin{array}{l}\text { Carried a } \\
\text { weapon }\end{array}$ & $\begin{array}{l}\text { No. of risky } \\
\text { beh. }\end{array}$ \\
\hline $\begin{array}{l}\text { Self-efficacy, } \\
\text { age } 15\end{array}$ & $\begin{array}{l}-0.038 \\
(0.284)\end{array}$ & $\begin{array}{l}-0.039 \\
(0.369)\end{array}$ & $\begin{array}{l}-0.020 \\
(0.688)\end{array}$ & $\begin{array}{l}-0.021 \\
(0.681)\end{array}$ & $\begin{array}{l}-0.022 \\
(0.627)\end{array}$ & $\begin{array}{c}0.010 \\
(0.840)\end{array}$ & $\begin{array}{l}-0.014 \\
(0.456)\end{array}$ & $\begin{array}{l}-0.133 \\
(0.292)\end{array}$ \\
\hline $\begin{array}{l}\text { Self-esteem, } \\
\text { age } 15\end{array}$ & $\begin{array}{l}-0.056^{* \star} \\
(0.029)\end{array}$ & $\begin{array}{l}-0.066^{*} \\
(0.054)\end{array}$ & $\begin{array}{l}-0.085^{* *} \\
(0.017)\end{array}$ & $\begin{array}{l}-0.020 \\
(0.488)\end{array}$ & $\begin{array}{l}-0.025 \\
(0.581)\end{array}$ & $\begin{array}{l}-0.138^{*} \\
(0.084)\end{array}$ & $\begin{array}{l}-0.037^{* *} \\
(0.044)\end{array}$ & $\begin{array}{l}-0.205^{* *} \\
(0.020)\end{array}$ \\
\hline Child is male & $\begin{array}{l}0.207^{* * *} \\
(0.000)\end{array}$ & $\begin{array}{l}0.217^{* * *} \\
(0.000)\end{array}$ & $\begin{array}{l}0.237^{* * *} \\
(0.000)\end{array}$ & $\begin{array}{l}0.130^{* * *} \\
(0.000)\end{array}$ & $\begin{array}{l}-0.034 \\
(0.480)\end{array}$ & $\begin{array}{l}0.111^{* *} \\
(0.019)\end{array}$ & $\begin{array}{l}0.001 \\
(0.970)\end{array}$ & $\begin{array}{l}0.521^{\text {*** }} \\
(0.000)\end{array}$ \\
\hline Age in R4 & $\begin{array}{l}0.095^{* * *} \\
(0.009)\end{array}$ & $\begin{array}{l}0.102^{* *} \\
(0.031)\end{array}$ & $\begin{array}{l}0.101^{* *} \\
(0.021)\end{array}$ & $\begin{array}{l}0.049^{* *} \\
(0.038)\end{array}$ & $\begin{array}{l}-0.006 \\
(0.914)\end{array}$ & $\begin{array}{c}0.007 \\
(0.849)\end{array}$ & $\begin{array}{l}-0.016 \\
(0.558)\end{array}$ & $\begin{array}{l}0.225^{\star \star} \\
(0.045)\end{array}$ \\
\hline $\begin{array}{l}\text { Type site: rural, } \\
\text { age } 15\end{array}$ & $\begin{array}{l}-0.049 \\
(0.599)\end{array}$ & $\begin{array}{l}-0.269^{* * *} \\
(0.000)\end{array}$ & $\begin{array}{l}-0.232^{* *} \\
(0.014)\end{array}$ & $\begin{array}{c}0.045 \\
(0.551)\end{array}$ & $\begin{array}{c}0.078 \\
(0.249)\end{array}$ & $\begin{array}{l}0.119 \\
(0.332)\end{array}$ & $\begin{array}{c}0.039 \\
(0.334)\end{array}$ & $\begin{array}{l}-0.156 \\
(0.430)\end{array}$ \\
\hline $\begin{array}{l}\text { Migrated between } \\
15 \text { and } 18\end{array}$ & $\begin{array}{c}0.074 \\
(0.446)\end{array}$ & $\begin{array}{l}0.171^{* *} \\
(0.037)\end{array}$ & $\begin{array}{l}0.216^{* *} \\
(0.018)\end{array}$ & $\begin{array}{l}-0.022 \\
(0.794)\end{array}$ & $\begin{array}{c}0.134 \\
(0.127)\end{array}$ & $\begin{array}{l}-0.080 \\
(0.531)\end{array}$ & $\begin{array}{l}-0.073^{*} \\
(0.063)\end{array}$ & $\begin{array}{c}0.283 \\
(0.313)\end{array}$ \\
\hline $\begin{array}{l}\text { Second tercile of } \\
\text { wealth, age } 15\end{array}$ & $\begin{array}{l}0.008 \\
(0.912)\end{array}$ & $\begin{array}{l}0.081 \\
(0.228)\end{array}$ & $\begin{array}{c}0.054 \\
(0.468)\end{array}$ & $\begin{array}{l}-0.006 \\
(0.792)\end{array}$ & $\begin{array}{l}0.019 \\
(0.721)\end{array}$ & $\begin{array}{l}-0.051 \\
(0.455)\end{array}$ & $\begin{array}{l}0.005 \\
(0.884)\end{array}$ & $\begin{array}{c}0.107 \\
(0.539)\end{array}$ \\
\hline $\begin{array}{l}\text { Third tercile of } \\
\text { wealth, age } 15\end{array}$ & $\begin{array}{l}-0.079 \\
(0.255)\end{array}$ & $\begin{array}{c}0.076 \\
(0.324)\end{array}$ & $\begin{array}{c}0.033 \\
(0.744)\end{array}$ & $\begin{array}{l}-0.010 \\
(0.851)\end{array}$ & $\begin{array}{c}0.093 \\
(0.244)\end{array}$ & $\begin{array}{l}-0.022 \\
(0.734)\end{array}$ & $\begin{array}{l}-0.017 \\
(0.602)\end{array}$ & $\begin{array}{c}0.062 \\
(0.730)\end{array}$ \\
\hline $\begin{array}{l}\text { Father's education } \\
\text { - Secondary } \\
\text { School }\end{array}$ & $\begin{array}{l}-0.016 \\
(0.766)\end{array}$ & $\begin{array}{c}0.044 \\
(0.472)\end{array}$ & $\begin{array}{c}0.081 \\
(0.162)\end{array}$ & $\begin{array}{l}-0.024 \\
(0.423)\end{array}$ & $\begin{array}{l}-0.009 \\
(0.885)\end{array}$ & $\begin{array}{l}-0.086^{*} \\
(0.076)\end{array}$ & $\begin{array}{l}-0.018 \\
(0.524)\end{array}$ & $\begin{array}{l}-0.024 \\
(0.879)\end{array}$ \\
\hline $\begin{array}{l}\text { Father's } \\
\text { education: higher } \\
\text { education }\end{array}$ & $\begin{array}{l}-0.013 \\
(0.818)\end{array}$ & $\begin{array}{c}0.012 \\
(0.860)\end{array}$ & $\begin{array}{l}0.051 \\
(0.484)\end{array}$ & $\begin{array}{l}-0.023 \\
(0.606)\end{array}$ & $\begin{array}{l}-0.072 \\
(0.356)\end{array}$ & $\begin{array}{l}-0.076 \\
(0.282)\end{array}$ & $\begin{array}{l}-0.056^{*} \\
(0.074)\end{array}$ & $\begin{array}{l}-0.151 \\
(0.350)\end{array}$ \\
\hline $\begin{array}{l}\text { Mother's } \\
\text { education: } \\
\text { secondary school }\end{array}$ & $\begin{array}{c}0.040 \\
(0.297)\end{array}$ & $\begin{array}{l}-0.034 \\
(0.309)\end{array}$ & $\begin{array}{l}-0.000 \\
(0.999)\end{array}$ & $\begin{array}{c}0.042 \\
(0.179)\end{array}$ & $\begin{array}{c}0.044 \\
(0.457)\end{array}$ & $\begin{array}{c}0.012 \\
(0.725)\end{array}$ & $\begin{array}{l}-0.012 \\
(0.611)\end{array}$ & $\begin{array}{c}0.080 \\
(0.387)\end{array}$ \\
\hline $\begin{array}{l}\text { Mother's } \\
\text { education: higher } \\
\text { education }\end{array}$ & $\begin{array}{c}0.054 \\
(0.495)\end{array}$ & $\begin{array}{l}0.004 \\
(0.964)\end{array}$ & $\begin{array}{l}0.046 \\
(0.568)\end{array}$ & $\begin{array}{c}0.073 \\
(0.261)\end{array}$ & $\begin{array}{l}-0.019 \\
(0.768)\end{array}$ & $\begin{array}{l}0.128 \\
(0.168)\end{array}$ & $\begin{array}{l}0.057^{*} \\
(0.056)\end{array}$ & $\begin{array}{c}0.170 \\
(0.424)\end{array}$ \\
\hline $\begin{array}{l}\text { Single parent, age } \\
15\end{array}$ & $\begin{array}{c}0.080 \\
(0.285)\end{array}$ & $\begin{array}{c}0.039 \\
(0.508)\end{array}$ & $\begin{array}{l}0.103^{*} \\
(0.079)\end{array}$ & $\begin{array}{c}0.076 \\
(0.198)\end{array}$ & $\begin{array}{l}0.154^{* * *} \\
(0.005)\end{array}$ & $\begin{array}{l}0.159^{* *} \\
(0.047)\end{array}$ & $\begin{array}{l}0.028 \\
(0.307)\end{array}$ & $\begin{array}{l}0.377^{* *} \\
(0.026)\end{array}$ \\
\hline $\begin{array}{l}\text { Child has older } \\
\text { siblings }\end{array}$ & $\begin{array}{l}0.019 \\
(0.549)\end{array}$ & $\begin{array}{l}0.057 \\
(0.212)\end{array}$ & $\begin{array}{l}0.067 \\
(0.125)\end{array}$ & $\begin{array}{l}0.027 \\
(0.434)\end{array}$ & $\begin{array}{l}-0.026 \\
(0.479)\end{array}$ & $\begin{array}{c}0.008 \\
(0.921)\end{array}$ & $\begin{array}{l}-0.001 \\
(0.947)\end{array}$ & $\begin{array}{c}0.076 \\
(0.453)\end{array}$ \\
\hline $\begin{array}{l}\text { Number of } \\
\text { siblings, age } 15\end{array}$ & $\begin{array}{l}-0.010 \\
(0.496)\end{array}$ & $\begin{array}{l}-0.017 \\
(0.357)\end{array}$ & $\begin{array}{l}-0.007 \\
(0.741)\end{array}$ & $\begin{array}{l}0.013 \\
(0.233)\end{array}$ & $\begin{array}{l}-0.004 \\
(0.773)\end{array}$ & $\begin{array}{l}0.045^{*} \\
(0.098)\end{array}$ & $\begin{array}{l}0.022^{*} \\
(0.095)\end{array}$ & $\begin{array}{c}0.004 \\
(0.905)\end{array}$ \\
\hline $\begin{array}{l}\text { Child is enrolled, } \\
\text { age } 15\end{array}$ & $\begin{array}{l}-0.086 \\
(0.310)\end{array}$ & $\begin{array}{l}-0.080 \\
(0.452)\end{array}$ & $\begin{array}{l}-0.130 \\
(0.155)\end{array}$ & $\begin{array}{l}-0.014 \\
(0.887)\end{array}$ & $\begin{array}{l}-0.047 \\
(0.507)\end{array}$ & $\begin{array}{l}-0.272^{\star \star} \\
(0.011)\end{array}$ & $\begin{array}{l}-0.062 \\
(0.492)\end{array}$ & $\begin{array}{l}-0.289 \\
(0.135)\end{array}$ \\
\hline $\begin{array}{l}\text { PPVT z-score, age } \\
15\end{array}$ & $\begin{array}{l}-0.041 \\
(0.180)\end{array}$ & $\begin{array}{l}-0.039 \\
(0.388)\end{array}$ & $\begin{array}{l}-0.015 \\
(0.699)\end{array}$ & $\begin{array}{l}-0.037 \\
(0.277)\end{array}$ & $\begin{array}{l}0.040 \\
(0.254)\end{array}$ & $\begin{array}{l}-0.027 \\
(0.650)\end{array}$ & $\begin{array}{l}0.014 \\
(0.413)\end{array}$ & $\begin{array}{l}-0.063 \\
(0.549)\end{array}$ \\
\hline $\begin{array}{l}\text { Maths z-score, } \\
\text { age } 15\end{array}$ & $\begin{array}{c}0.010 \\
(0.663) \\
\end{array}$ & $\begin{array}{l}0.001 \\
(0.956)\end{array}$ & $\begin{array}{l}-0.023 \\
(0.283) \\
\end{array}$ & $\begin{array}{l}-0.012 \\
(0.553) \\
\end{array}$ & $\begin{array}{l}-0.018 \\
(0.516) \\
\end{array}$ & $\begin{array}{l}-0.011 \\
(0.663) \\
\end{array}$ & $\begin{array}{l}-0.016 \\
(0.174) \\
\end{array}$ & $\begin{array}{l}-0.035 \\
(0.444) \\
\end{array}$ \\
\hline $\begin{array}{l}\text { Number of } \\
\text { observations }\end{array}$ & 471 & 471 & 471 & 471 & 471 & 471 & 471 & 471 \\
\hline R-squared & 0.209 & 0.185 & 0.189 & 0.124 & 0.107 & 0.133 & 0.097 & 0.174 \\
\hline
\end{tabular}

Note: The table reports the estimates of the linear probability model with standard errors (in parentheses) clustered at cluster level, ${ }^{*} p<0.1{ }^{* *} p<0.05$ ${ }^{* * *} p<0.1$. All controls were included as reported, together with dummy variables for the cluster that individuals were recruited in the 2002 round; coefficients for these are not reported. 
Table 6. Predictors of risky behaviours at age 19 controlling for educational aspirations and other characteristics at age 15

\begin{tabular}{|c|c|c|c|c|c|c|c|c|}
\hline & Smoking & Drinking & $\begin{array}{c}\text { Drinking \& } \\
\text { violence }\end{array}$ & $\begin{array}{c}\text { Drugs } \\
\text { consumption }\end{array}$ & $\begin{array}{l}\text { Unprotected } \\
\text { sex }\end{array}$ & $\begin{array}{l}\text { Criminal } \\
\text { beh. }\end{array}$ & $\begin{array}{l}\text { Carried a } \\
\text { weapon }\end{array}$ & $\begin{array}{l}\text { No. of } \\
\text { risky beh. }\end{array}$ \\
\hline $\begin{array}{l}\text { Child aspired to } \\
\text { higher education, } \\
\text { age } 15\end{array}$ & $\begin{array}{l}-0.119 \\
(0.292)\end{array}$ & $\begin{array}{l}-0.142^{*} \\
(0.070)\end{array}$ & $\begin{array}{l}-0.124 \\
(0.171)\end{array}$ & $\begin{array}{l}-0.109 \\
(0.251)\end{array}$ & $\begin{array}{l}-0.100 \\
(0.155)\end{array}$ & $\begin{array}{l}-0.245^{\star} \\
(0.051)\end{array}$ & $\begin{array}{l}-0.064 \\
(0.347)\end{array}$ & $\begin{array}{l}-0.534^{*} \\
(0.054)\end{array}$ \\
\hline Child is male & $\begin{array}{l}0.209^{\star * *} \\
(0.000)\end{array}$ & $\begin{array}{l}0.219^{* \star *} \\
(0.000)\end{array}$ & $\begin{array}{l}0.237^{\star * *} \\
(0.000)\end{array}$ & $\begin{array}{l}0.130^{* * *} \\
(0.000)\end{array}$ & $\begin{array}{l}-0.034 \\
(0.514)\end{array}$ & $\begin{array}{l}0.104^{\star *} \\
(0.020)\end{array}$ & $\begin{array}{c}0.001 \\
(0.954)\end{array}$ & $\begin{array}{l}0.526^{\star * *} \\
(0.000)\end{array}$ \\
\hline Age in R4 & $\begin{array}{l}0.092^{* *} \\
(0.013)\end{array}$ & $\begin{array}{l}0.100^{* *} \\
(0.036)\end{array}$ & $\begin{array}{l}0.098^{* *} \\
(0.027)\end{array}$ & $\begin{array}{l}0.048^{* *} \\
(0.041)\end{array}$ & $\begin{array}{l}-0.007 \\
(0.888)\end{array}$ & $\begin{array}{c}0.005 \\
(0.887)\end{array}$ & $\begin{array}{l}-0.017 \\
(0.520)\end{array}$ & $\begin{array}{l}0.215^{\star *} \\
(0.049)\end{array}$ \\
\hline $\begin{array}{l}\text { Type site: rural, } \\
\text { age } 15\end{array}$ & $\begin{array}{l}-0.057 \\
(0.551)\end{array}$ & $\begin{array}{l}-0.278^{* \star *} \\
(0.000)\end{array}$ & $\begin{array}{l}-0.240^{\star *} \\
(0.012)\end{array}$ & $\begin{array}{c}0.038 \\
(0.598)\end{array}$ & $\begin{array}{c}0.072 \\
(0.271)\end{array}$ & $\begin{array}{c}0.105 \\
(0.382)\end{array}$ & $\begin{array}{c}0.035 \\
(0.319)\end{array}$ & $\begin{array}{l}-0.191 \\
(0.323)\end{array}$ \\
\hline $\begin{array}{l}\text { Migrated between } \\
15 \text { and } 18\end{array}$ & $\begin{array}{c}0.088 \\
(0.300)\end{array}$ & $\begin{array}{l}0.187^{* *} \\
(0.011)\end{array}$ & $\begin{array}{l}0.232^{* * *} \\
(0.006)\end{array}$ & $\begin{array}{l}-0.012 \\
(0.875)\end{array}$ & $\begin{array}{l}0.144^{*} \\
(0.089)\end{array}$ & $\begin{array}{l}-0.051 \\
(0.645)\end{array}$ & $\begin{array}{l}-0.065 \\
(0.129)\end{array}$ & $\begin{array}{c}0.342 \\
(0.140)\end{array}$ \\
\hline $\begin{array}{l}\text { Second tercile of } \\
\text { wealth, age } 15\end{array}$ & $\begin{array}{c}0.001 \\
(0.988)\end{array}$ & $\begin{array}{c}0.073 \\
(0.243)\end{array}$ & $\begin{array}{c}0.045 \\
(0.526)\end{array}$ & $\begin{array}{l}-0.008 \\
(0.688)\end{array}$ & $\begin{array}{c}0.016 \\
(0.759)\end{array}$ & $\begin{array}{l}-0.063 \\
(0.309)\end{array}$ & $\begin{array}{c}0.001 \\
(0.969)\end{array}$ & $\begin{array}{c}0.084 \\
(0.603)\end{array}$ \\
\hline $\begin{array}{l}\text { Third tercile of } \\
\text { wealth, age } 15\end{array}$ & $\begin{array}{l}-0.088 \\
(0.203)\end{array}$ & $\begin{array}{c}0.065 \\
(0.386)\end{array}$ & $\begin{array}{c}0.019 \\
(0.844)\end{array}$ & $\begin{array}{l}-0.011 \\
(0.830)\end{array}$ & $\begin{array}{c}0.089 \\
(0.245)\end{array}$ & $\begin{array}{l}-0.038 \\
(0.575)\end{array}$ & $\begin{array}{l}-0.023 \\
(0.476)\end{array}$ & $\begin{array}{c}0.032 \\
(0.856)\end{array}$ \\
\hline $\begin{array}{l}\text { Father's } \\
\text { education: } \\
\text { secondary school }\end{array}$ & $\begin{array}{l}-0.018 \\
(0.740)\end{array}$ & $\begin{array}{c}0.042 \\
(0.500)\end{array}$ & $\begin{array}{c}0.077 \\
(0.173)\end{array}$ & $\begin{array}{l}-0.023 \\
(0.462)\end{array}$ & $\begin{array}{l}-0.008 \\
(0.895)\end{array}$ & $\begin{array}{l}-0.089^{*} \\
(0.078)\end{array}$ & $\begin{array}{l}-0.020 \\
(0.487)\end{array}$ & $\begin{array}{l}-0.027 \\
(0.864)\end{array}$ \\
\hline $\begin{array}{l}\text { Father's } \\
\text { education: higher } \\
\text { education }\end{array}$ & $\begin{array}{l}-0.019 \\
(0.721)\end{array}$ & $\begin{array}{c}0.004 \\
(0.954)\end{array}$ & $\begin{array}{c}0.044 \\
(0.529)\end{array}$ & $\begin{array}{l}-0.027 \\
(0.542)\end{array}$ & $\begin{array}{l}-0.077 \\
(0.333)\end{array}$ & $\begin{array}{l}-0.085 \\
(0.219)\end{array}$ & $\begin{array}{l}-0.059^{*} \\
(0.067)\end{array}$ & $\begin{array}{l}-0.178 \\
(0.285)\end{array}$ \\
\hline $\begin{array}{l}\text { Mother's } \\
\text { education: } \\
\text { secondary School }\end{array}$ & $\begin{array}{c}0.036 \\
(0.370)\end{array}$ & $\begin{array}{l}-0.039 \\
(0.264)\end{array}$ & $\begin{array}{l}-0.005 \\
(0.884)\end{array}$ & $\begin{array}{l}0.041 \\
(0.154)\end{array}$ & $\begin{array}{c}0.043 \\
(0.453)\end{array}$ & $\begin{array}{c}0.010 \\
(0.736)\end{array}$ & $\begin{array}{l}-0.014 \\
(0.503)\end{array}$ & $\begin{array}{c}0.067 \\
(0.382)\end{array}$ \\
\hline $\begin{array}{l}\text { Mother's } \\
\text { education: higher } \\
\text { education }\end{array}$ & $\begin{array}{c}0.043 \\
(0.599)\end{array}$ & $\begin{array}{l}-0.010 \\
(0.904)\end{array}$ & $\begin{array}{c}0.027 \\
(0.736)\end{array}$ & $\begin{array}{c}0.072 \\
(0.262)\end{array}$ & $\begin{array}{l}-0.022 \\
(0.708)\end{array}$ & $\begin{array}{c}0.100 \\
(0.347)\end{array}$ & $\begin{array}{c}0.049 \\
(0.109)\end{array}$ & $\begin{array}{c}0.132 \\
(0.520)\end{array}$ \\
\hline $\begin{array}{l}\text { Single parent, age } \\
15\end{array}$ & $\begin{array}{c}0.078 \\
(0.285)\end{array}$ & $\begin{array}{l}0.037 \\
(0.521)\end{array}$ & $\begin{array}{l}0.100^{*} \\
(0.084)\end{array}$ & $\begin{array}{l}0.075 \\
(0.188)\end{array}$ & $\begin{array}{l}0.154^{* * *} \\
(0.006)\end{array}$ & $\begin{array}{l}0.154^{* *} \\
(0.046)\end{array}$ & $\begin{array}{c}0.027 \\
(0.327)\end{array}$ & $\begin{array}{l}0.372^{\star *} \\
(0.026)\end{array}$ \\
\hline $\begin{array}{l}\text { Child has older } \\
\text { siblings }\end{array}$ & $\begin{array}{l}0.010 \\
(0.739)\end{array}$ & $\begin{array}{c}0.047 \\
(0.280)\end{array}$ & $\begin{array}{c}0.058 \\
(0.177)\end{array}$ & $\begin{array}{c}0.024 \\
(0.480)\end{array}$ & $\begin{array}{l}-0.030 \\
(0.359)\end{array}$ & $\begin{array}{l}-0.001 \\
(0.991)\end{array}$ & $\begin{array}{l}-0.006 \\
(0.742)\end{array}$ & $\begin{array}{l}0.046 \\
(0.622)\end{array}$ \\
\hline $\begin{array}{l}\text { Number of } \\
\text { siblings, age } 15\end{array}$ & $\begin{array}{l}-0.014 \\
(0.378)\end{array}$ & $\begin{array}{l}-0.021 \\
(0.264)\end{array}$ & $\begin{array}{l}-0.012 \\
(0.607)\end{array}$ & $\begin{array}{c}0.012 \\
(0.313)\end{array}$ & $\begin{array}{l}-0.006 \\
(0.688)\end{array}$ & $\begin{array}{c}0.039 \\
(0.134)\end{array}$ & $\begin{array}{c}0.020 \\
(0.130)\end{array}$ & $\begin{array}{l}-0.009 \\
(0.823)\end{array}$ \\
\hline $\begin{array}{l}\text { Child is enrolled, } \\
\text { age } 15\end{array}$ & $\begin{array}{l}-0.054 \\
(0.596)\end{array}$ & $\begin{array}{l}-0.041 \\
(0.716)\end{array}$ & $\begin{array}{l}-0.094 \\
(0.332)\end{array}$ & $\begin{array}{c}0.017 \\
(0.867)\end{array}$ & $\begin{array}{l}-0.020 \\
(0.799)\end{array}$ & $\begin{array}{l}-0.196 \\
(0.117)\end{array}$ & $\begin{array}{l}-0.044 \\
(0.660)\end{array}$ & $\begin{array}{l}-0.143 \\
(0.530)\end{array}$ \\
\hline $\begin{array}{l}\text { PPVT z-score, age } \\
15\end{array}$ & $\begin{array}{l}-0.043 \\
(0.143)\end{array}$ & $\begin{array}{l}-0.041 \\
(0.372)\end{array}$ & $\begin{array}{l}-0.017 \\
(0.658)\end{array}$ & $\begin{array}{l}-0.035 \\
(0.265)\end{array}$ & $\begin{array}{c}0.042 \\
(0.224)\end{array}$ & $\begin{array}{l}-0.024 \\
(0.672)\end{array}$ & $\begin{array}{c}0.013 \\
(0.430)\end{array}$ & $\begin{array}{l}-0.064 \\
(0.517)\end{array}$ \\
\hline $\begin{array}{l}\text { Maths z-score, } \\
\text { age } 15\end{array}$ & $\begin{array}{c}0.012 \\
(0.547)\end{array}$ & $\begin{array}{c}0.004 \\
(0.811)\end{array}$ & $\begin{array}{l}-0.018 \\
(0.387)\end{array}$ & $\begin{array}{l}-0.012 \\
(0.564)\end{array}$ & $\begin{array}{l}-0.017 \\
(0.556)\end{array}$ & $\begin{array}{l}-0.001 \\
(0.967)\end{array}$ & $\begin{array}{l}-0.014 \\
(0.238)\end{array}$ & $\begin{array}{l}-0.027 \\
(0.545)\end{array}$ \\
\hline $\begin{array}{l}\text { Number of } \\
\text { observations }\end{array}$ & 471 & 471 & 471 & 471 & 471 & 471 & 471 & 471 \\
\hline R-squared & 0.204 & 0.180 & 0.181 & 0.127 & 0.108 & 0.124 & 0.090 & 0.169 \\
\hline
\end{tabular}

Note: The table reports the estimates of the linear probability model with standard errors (in parentheses) clustered at cluster level, ${ }^{*} p<0.1{ }^{* *} p<0.05$ ${ }^{* * *} p<0.1$. All controls were included as reported, together with dummy variables for the cluster that individuals were recruited in the 2002 round; coefficients for these are not reported. 
Table 7. Predictors of risky behaviours at age 19: heterogeneity in psychosocial competencies by gender

\begin{tabular}{|c|c|c|c|c|c|c|c|c|}
\hline & Smoking & Drinking & $\begin{array}{c}\text { Drinking \& } \\
\text { violence }\end{array}$ & $\begin{array}{c}\text { Drugs } \\
\text { consumption }\end{array}$ & $\begin{array}{l}\text { Unprotected } \\
\text { sex }\end{array}$ & $\begin{array}{c}\text { Criminal } \\
\text { beh. }\end{array}$ & $\begin{array}{l}\text { Carried a } \\
\text { weapon }\end{array}$ & $\begin{array}{l}\text { No. of } \\
\text { risky beh. }\end{array}$ \\
\hline $\begin{array}{l}\text { Self-efficacy, age } \\
15\end{array}$ & $\begin{array}{l}-0.067 \\
(0.232)\end{array}$ & $\begin{array}{l}-0.003 \\
(0.941)\end{array}$ & $\begin{array}{c}0.014 \\
(0.778)\end{array}$ & $\begin{array}{l}-0.048 \\
(0.243)\end{array}$ & $\begin{array}{l}-0.068 \\
(0.371)\end{array}$ & $\begin{array}{l}-0.006 \\
(0.924)\end{array}$ & $\begin{array}{l}-0.042 \\
(0.156)\end{array}$ & $\begin{array}{l}-0.228 \\
(0.101)\end{array}$ \\
\hline $\begin{array}{l}\text { Self-esteem, age } \\
15\end{array}$ & $\begin{array}{l}-0.012 \\
(0.659)\end{array}$ & $\begin{array}{l}-0.061 \\
(0.161)\end{array}$ & $\begin{array}{l}-0.051 \\
(0.331)\end{array}$ & $\begin{array}{l}-0.024 \\
(0.514)\end{array}$ & $\begin{array}{l}-0.040 \\
(0.483)\end{array}$ & $\begin{array}{l}-0.093 \\
(0.136)\end{array}$ & $\begin{array}{l}-0.035^{*} \\
(0.094)\end{array}$ & $\begin{array}{l}-0.171^{*} \\
(0.059)\end{array}$ \\
\hline $\begin{array}{l}\text { Male } x \text { self- } \\
\text { efficacy, age } 15\end{array}$ & $\begin{array}{c}0.052 \\
(0.556)\end{array}$ & $\begin{array}{l}-0.063 \\
(0.391)\end{array}$ & $\begin{array}{l}-0.059 \\
(0.369)\end{array}$ & $\begin{array}{c}0.048 \\
(0.468)\end{array}$ & $\begin{array}{c}0.081 \\
(0.446)\end{array}$ & $\begin{array}{c}0.030 \\
(0.751)\end{array}$ & $\begin{array}{c}0.051 \\
(0.179)\end{array}$ & $\begin{array}{c}0.168 \\
(0.510)\end{array}$ \\
\hline $\begin{array}{l}\text { Male } \times \text { self-esteem, } \\
\text { age } 15\end{array}$ & $\begin{array}{l}-0.092 \\
(0.143)\end{array}$ & $\begin{array}{l}-0.012 \\
(0.848)\end{array}$ & $\begin{array}{l}-0.071 \\
(0.388)\end{array}$ & $\begin{array}{c}0.006 \\
(0.888)\end{array}$ & $\begin{array}{c}0.030 \\
(0.732)\end{array}$ & $\begin{array}{l}-0.095 \\
(0.355)\end{array}$ & $\begin{array}{l}-0.003 \\
(0.949)\end{array}$ & $\begin{array}{l}-0.071 \\
(0.610)\end{array}$ \\
\hline Child is male & $\begin{array}{l}0.206^{\star * *} \\
(0.000)\end{array}$ & $\begin{array}{l}0.220^{* * *} \\
(0.000)\end{array}$ & $\begin{array}{l}0.240^{* * *} \\
(0.000)\end{array}$ & $\begin{array}{l}0.128^{* * *} \\
(0.001)\end{array}$ & $\begin{array}{l}-0.037 \\
(0.441)\end{array}$ & $\begin{array}{l}0.110^{* *} \\
(0.023)\end{array}$ & $\begin{array}{l}-0.001 \\
(0.960)\end{array}$ & $\begin{array}{l}0.516^{* * *} \\
(0.000)\end{array}$ \\
\hline Age in $\mathrm{R} 4$ & $\begin{array}{l}0.098^{* * *} \\
(0.006)\end{array}$ & $\begin{array}{l}0.100^{* *} \\
(0.036)\end{array}$ & $\begin{array}{l}0.099^{* *} \\
(0.027)\end{array}$ & $\begin{array}{l}0.051^{* *} \\
(0.027)\end{array}$ & $\begin{array}{l}-0.002 \\
(0.963)\end{array}$ & $\begin{array}{c}0.010 \\
(0.788)\end{array}$ & $\begin{array}{l}-0.014 \\
(0.614)\end{array}$ & $\begin{array}{l}0.234^{* *} \\
(0.037)\end{array}$ \\
\hline $\begin{array}{l}\text { Type site: rural, } \\
\text { age } 15\end{array}$ & $\begin{array}{l}-0.037 \\
(0.705)\end{array}$ & $\begin{array}{l}-0.262^{* * *} \\
(0.000)\end{array}$ & $\begin{array}{l}-0.215^{* *} \\
(0.030)\end{array}$ & $\begin{array}{c}0.040 \\
(0.591)\end{array}$ & $\begin{array}{c}0.066 \\
(0.358)\end{array}$ & $\begin{array}{c}0.134 \\
(0.256)\end{array}$ & $\begin{array}{c}0.036 \\
(0.351)\end{array}$ & $\begin{array}{l}-0.157 \\
(0.441)\end{array}$ \\
\hline $\begin{array}{l}\text { Migrated between } \\
15 \text { and } 18\end{array}$ & $\begin{array}{c}0.066 \\
(0.498)\end{array}$ & $\begin{array}{c}0.167^{*} \\
(0.051)\end{array}$ & $\begin{array}{l}0.205^{\star *} \\
(0.033)\end{array}$ & $\begin{array}{l}-0.019 \\
(0.824)\end{array}$ & $\begin{array}{c}0.141^{*} \\
(0.095)\end{array}$ & $\begin{array}{l}-0.088 \\
(0.483)\end{array}$ & $\begin{array}{l}-0.070^{* *} \\
(0.050)\end{array}$ & $\begin{array}{c}0.284 \\
(0.306)\end{array}$ \\
\hline $\begin{array}{l}\text { Second tercile of } \\
\text { wealth, age } 15\end{array}$ & $\begin{array}{c}0.014 \\
(0.839)\end{array}$ & $\begin{array}{c}0.082 \\
(0.229)\end{array}$ & $\begin{array}{c}0.059 \\
(0.426)\end{array}$ & $\begin{array}{l}-0.007 \\
(0.776)\end{array}$ & $\begin{array}{c}0.017 \\
(0.743)\end{array}$ & $\begin{array}{l}-0.045 \\
(0.511)\end{array}$ & $\begin{array}{c}0.005 \\
(0.883)\end{array}$ & $\begin{array}{c}0.112 \\
(0.523)\end{array}$ \\
\hline $\begin{array}{l}\text { Third tercile of } \\
\text { wealth, age } 15\end{array}$ & $\begin{array}{l}-0.069 \\
(0.306)\end{array}$ & $\begin{array}{c}0.075 \\
(0.326)\end{array}$ & $\begin{array}{c}0.037 \\
(0.706)\end{array}$ & $\begin{array}{l}-0.009 \\
(0.871)\end{array}$ & $\begin{array}{c}0.093 \\
(0.239)\end{array}$ & $\begin{array}{l}-0.012 \\
(0.839)\end{array}$ & $\begin{array}{l}-0.015 \\
(0.652)\end{array}$ & $\begin{array}{c}0.075 \\
(0.677)\end{array}$ \\
\hline $\begin{array}{l}\text { Father's education: } \\
\text { secondary School }\end{array}$ & $\begin{array}{l}-0.018 \\
(0.738)\end{array}$ & $\begin{array}{c}0.045 \\
(0.466)\end{array}$ & $\begin{array}{c}0.081 \\
(0.151)\end{array}$ & $\begin{array}{l}-0.025 \\
(0.420)\end{array}$ & $\begin{array}{l}-0.010 \\
(0.876)\end{array}$ & $\begin{array}{l}-0.087^{*} \\
(0.070)\end{array}$ & $\begin{array}{l}-0.019 \\
(0.510)\end{array}$ & $\begin{array}{l}-0.027 \\
(0.865)\end{array}$ \\
\hline $\begin{array}{l}\text { Father's education: } \\
\text { higher education }\end{array}$ & $\begin{array}{l}-0.016 \\
(0.765)\end{array}$ & $\begin{array}{c}0.014 \\
(0.833)\end{array}$ & $\begin{array}{l}0.052 \\
(0.468)\end{array}$ & $\begin{array}{l}-0.024 \\
(0.557)\end{array}$ & $\begin{array}{l}-0.075 \\
(0.353)\end{array}$ & $\begin{array}{l}-0.079 \\
(0.254)\end{array}$ & $\begin{array}{l}-0.057^{*} \\
(0.067)\end{array}$ & $\begin{array}{l}-0.158 \\
(0.321)\end{array}$ \\
\hline $\begin{array}{l}\text { Mother's } \\
\text { education: } \\
\text { secondary School }\end{array}$ & $\begin{array}{c}0.040 \\
(0.308)\end{array}$ & $\begin{array}{l}-0.034 \\
(0.304)\end{array}$ & $\begin{array}{l}-0.001 \\
(0.982)\end{array}$ & $\begin{array}{c}0.042 \\
(0.177)\end{array}$ & $\begin{array}{c}0.044 \\
(0.458)\end{array}$ & $\begin{array}{l}0.011 \\
(0.742)\end{array}$ & $\begin{array}{l}-0.012 \\
(0.605)\end{array}$ & $\begin{array}{c}0.080 \\
(0.385)\end{array}$ \\
\hline $\begin{array}{l}\text { Mother's } \\
\text { education: higher } \\
\text { education }\end{array}$ & $\begin{array}{c}0.054 \\
(0.484)\end{array}$ & $\begin{array}{c}0.000 \\
(0.996)\end{array}$ & $\begin{array}{c}0.042 \\
(0.593)\end{array}$ & $\begin{array}{c}0.076 \\
(0.246)\end{array}$ & $\begin{array}{l}-0.014 \\
(0.817)\end{array}$ & $\begin{array}{c}0.127 \\
(0.156)\end{array}$ & $\begin{array}{l}0.059^{* *} \\
(0.030)\end{array}$ & $\begin{array}{c}0.176 \\
(0.402)\end{array}$ \\
\hline $\begin{array}{l}\text { Single parent, age } \\
15\end{array}$ & $\begin{array}{c}0.080 \\
(0.285)\end{array}$ & $\begin{array}{c}0.039 \\
(0.512)\end{array}$ & $\begin{array}{l}0.103^{*} \\
(0.082)\end{array}$ & $\begin{array}{l}0.076 \\
(0.193)\end{array}$ & $\begin{array}{l}0.154^{\star * *} \\
(0.006)\end{array}$ & $\begin{array}{l}0.159^{* *} \\
(0.047)\end{array}$ & $\begin{array}{c}0.028 \\
(0.302)\end{array}$ & $\begin{array}{l}0.377^{* *} \\
(0.025)\end{array}$ \\
\hline $\begin{array}{l}\text { Child has older } \\
\text { siblings }\end{array}$ & $\begin{array}{c}0.018 \\
(0.586)\end{array}$ & $\begin{array}{c}0.054 \\
(0.238)\end{array}$ & $\begin{array}{c}0.062 \\
(0.148)\end{array}$ & $\begin{array}{c}0.029 \\
(0.429)\end{array}$ & $\begin{array}{l}-0.022 \\
(0.550)\end{array}$ & $\begin{array}{c}0.005 \\
(0.943)\end{array}$ & $\begin{array}{c}0.000 \\
(0.986)\end{array}$ & $\begin{array}{c}0.080 \\
(0.440)\end{array}$ \\
\hline $\begin{array}{l}\text { Number of siblings, } \\
\text { age } 15\end{array}$ & $\begin{array}{l}-0.010 \\
(0.482)\end{array}$ & $\begin{array}{l}-0.017 \\
(0.361)\end{array}$ & $\begin{array}{l}-0.008 \\
(0.738)\end{array}$ & $\begin{array}{c}0.013 \\
(0.233)\end{array}$ & $\begin{array}{l}-0.004 \\
(0.769)\end{array}$ & $\begin{array}{c}0.045^{*} \\
(0.096)\end{array}$ & $\begin{array}{c}0.022^{*} \\
(0.099)\end{array}$ & $\begin{array}{c}0.004 \\
(0.917)\end{array}$ \\
\hline $\begin{array}{l}\text { Chils is enrolled, } \\
\text { age } 15\end{array}$ & $\begin{array}{l}-0.071 \\
(0.422)\end{array}$ & $\begin{array}{l}-0.076 \\
(0.492)\end{array}$ & $\begin{array}{l}-0.115 \\
(0.228)\end{array}$ & $\begin{array}{l}-0.016 \\
(0.867)\end{array}$ & $\begin{array}{l}-0.055 \\
(0.460)\end{array}$ & $\begin{array}{l}-0.255^{* * *} \\
(0.009)\end{array}$ & $\begin{array}{l}-0.063 \\
(0.475)\end{array}$ & $\begin{array}{l}-0.281 \\
(0.164)\end{array}$ \\
\hline $\begin{array}{l}\text { PPVT z-score, age } \\
15\end{array}$ & $\begin{array}{l}-0.040 \\
(0.166)\end{array}$ & $\begin{array}{l}-0.040 \\
(0.384)\end{array}$ & $\begin{array}{l}-0.015 \\
(0.687)\end{array}$ & $\begin{array}{l}-0.037 \\
(0.275)\end{array}$ & $\begin{array}{c}0.041 \\
(0.247)\end{array}$ & $\begin{array}{l}-0.026 \\
(0.651)\end{array}$ & $\begin{array}{c}0.014 \\
(0.387)\end{array}$ & $\begin{array}{l}-0.062 \\
(0.552)\end{array}$ \\
\hline $\begin{array}{l}\text { Maths z-score, age } \\
15\end{array}$ & $\begin{array}{c}0.011 \\
(0.632)\end{array}$ & $\begin{array}{c}0.001 \\
(0.943)\end{array}$ & $\begin{array}{l}-0.022 \\
(0.319)\end{array}$ & $\begin{array}{l}-0.013 \\
(0.546)\end{array}$ & $\begin{array}{l}-0.018 \\
(0.505)\end{array}$ & $\begin{array}{l}-0.011 \\
(0.697)\end{array}$ & $\begin{array}{l}-0.016 \\
(0.174)\end{array}$ & $\begin{array}{l}-0.035 \\
(0.445)\end{array}$ \\
\hline $\begin{array}{l}\text { Number of } \\
\text { observations }\end{array}$ & 471 & 471 & 471 & 471 & 471 & 471 & 471 & 471 \\
\hline R-squared & 0.214 & 0.186 & 0.192 & 0.125 & 0.110 & 0.135 & 0.100 & 0.175 \\
\hline
\end{tabular}

Note: The table reports the estimates of the linear probability model with standard errors (in parentheses) clustered at cluster level, ${ }^{*} p<0.1{ }^{* *} \mathrm{p}<0.05$ ${ }^{* * *} \mathrm{p}<0.1$. All controls were included as reported, together with dummy variables for the cluster that individuals were recruited in the 2002 round; coefficients for these are not reported. 
Table 8. Predictors of risky behaviours at age 19: heterogeneity in educational aspirations by gender

\begin{tabular}{|c|c|c|c|c|c|c|c|c|}
\hline & Smoking & Drinking & $\begin{array}{c}\text { Drinking \& } \\
\text { Violence }\end{array}$ & $\begin{array}{c}\text { Drugs } \\
\text { consumption }\end{array}$ & $\begin{array}{l}\text { Unprotected } \\
\text { sex }\end{array}$ & $\begin{array}{c}\text { Criminal } \\
\text { beh. }\end{array}$ & $\begin{array}{l}\text { Carried a } \\
\text { weapon }\end{array}$ & $\begin{array}{l}\text { No. of } \\
\text { risky beh. }\end{array}$ \\
\hline $\begin{array}{l}\text { Child aspired for } \\
\text { higher education, } \\
\text { age } 15\end{array}$ & $\begin{array}{l}-0.134 \\
(0.423)\end{array}$ & $\begin{array}{l}-0.230 \\
(0.103)\end{array}$ & $\begin{array}{l}-0.210 \\
(0.231)\end{array}$ & $\begin{array}{l}-0.010 \\
(0.909)\end{array}$ & $\begin{array}{l}-0.278^{* *} \\
(0.015)\end{array}$ & $\begin{array}{l}-0.303 \\
(0.209)\end{array}$ & $\begin{array}{l}-0.196 \\
(0.157)\end{array}$ & $\begin{array}{l}-0.848^{*} \\
(0.050)\end{array}$ \\
\hline $\begin{array}{l}\text { Male } \times \text { Child } \\
\text { aspired for higher } \\
\text { education, age } 15\end{array}$ & $\begin{array}{c}0.027 \\
(0.886)\end{array}$ & $\begin{array}{l}0.150 \\
(0.443)\end{array}$ & $\begin{array}{c}0.146 \\
(0.524)\end{array}$ & $\begin{array}{l}-0.169 \\
(0.163)\end{array}$ & $\begin{array}{l}0.303^{*} \\
(0.061)\end{array}$ & $\begin{array}{c}0.099 \\
(0.689)\end{array}$ & $\begin{array}{c}0.226 \\
(0.134)\end{array}$ & $\begin{array}{c}0.536 \\
(0.288)\end{array}$ \\
\hline Child is male & $\begin{array}{c}0.185 \\
(0.287)\end{array}$ & $\begin{array}{c}0.079 \\
(0.659)\end{array}$ & $\begin{array}{c}0.101 \\
(0.639)\end{array}$ & $\begin{array}{l}0.288^{* *} \\
(0.012)\end{array}$ & $\begin{array}{l}-0.316^{*} \\
(0.081)\end{array}$ & $\begin{array}{c}0.012 \\
(0.963)\end{array}$ & $\begin{array}{l}-0.209 \\
(0.169)\end{array}$ & $\begin{array}{c}0.026 \\
(0.956)\end{array}$ \\
\hline Age in R4 & $\begin{array}{l}0.092^{\star *} \\
(0.015)\end{array}$ & $\begin{array}{l}0.098^{* *} \\
(0.040)\end{array}$ & $\begin{array}{l}0.097^{\star \star} \\
(0.031)\end{array}$ & $\begin{array}{l}0.050^{\star *} \\
(0.035)\end{array}$ & $\begin{array}{l}-0.010 \\
(0.837)\end{array}$ & $\begin{array}{c}0.004 \\
(0.912)\end{array}$ & $\begin{array}{l}-0.020 \\
(0.467)\end{array}$ & $\begin{array}{l}0.210^{*} \\
(0.060)\end{array}$ \\
\hline $\begin{array}{l}\text { Type site - Rural, } \\
\text { age } 15\end{array}$ & $\begin{array}{l}-0.058 \\
(0.529)\end{array}$ & $\begin{array}{l}-0.285^{\star * *} \\
(0.000)\end{array}$ & $\begin{array}{l}-0.247^{\star \star *} \\
(0.010)\end{array}$ & $\begin{array}{c}0.045 \\
(0.532)\end{array}$ & $\begin{array}{c}0.058 \\
(0.367)\end{array}$ & $\begin{array}{c}0.100 \\
(0.385)\end{array}$ & $\begin{array}{c}0.025 \\
(0.448)\end{array}$ & $\begin{array}{l}-0.215 \\
(0.245)\end{array}$ \\
\hline $\begin{array}{l}\text { Migrated between } \\
15 \text { and } 18\end{array}$ & $\begin{array}{c}0.089 \\
(0.288)\end{array}$ & $\begin{array}{l}0.193^{* * *} \\
(0.009)\end{array}$ & $\begin{array}{l}0.237^{* * *} \\
(0.005)\end{array}$ & $\begin{array}{l}-0.018 \\
(0.815)\end{array}$ & $\begin{array}{c}0.155^{*} \\
(0.064)\end{array}$ & $\begin{array}{l}-0.047 \\
(0.657)\end{array}$ & $\begin{array}{l}-0.056 \\
(0.234)\end{array}$ & $\begin{array}{c}0.362^{*} \\
(0.090)\end{array}$ \\
\hline $\begin{array}{l}\text { Second tercile of } \\
\text { wealth, age } 15\end{array}$ & $\begin{array}{c}0.002 \\
(0.983)\end{array}$ & $\begin{array}{c}0.076 \\
(0.221)\end{array}$ & $\begin{array}{c}0.048 \\
(0.505)\end{array}$ & $\begin{array}{l}-0.012 \\
(0.583)\end{array}$ & $\begin{array}{c}0.022 \\
(0.672)\end{array}$ & $\begin{array}{l}-0.061 \\
(0.322)\end{array}$ & $\begin{array}{c}0.006 \\
(0.871)\end{array}$ & $\begin{array}{c}0.094 \\
(0.553)\end{array}$ \\
\hline $\begin{array}{l}\text { Third tercile of } \\
\text { wealth, age } 15\end{array}$ & $\begin{array}{l}-0.088 \\
(0.207)\end{array}$ & $\begin{array}{c}0.066 \\
(0.377)\end{array}$ & $\begin{array}{c}0.021 \\
(0.836)\end{array}$ & $\begin{array}{l}-0.013 \\
(0.808)\end{array}$ & $\begin{array}{c}0.092 \\
(0.228)\end{array}$ & $\begin{array}{l}-0.037 \\
(0.586)\end{array}$ & $\begin{array}{l}-0.021 \\
(0.505)\end{array}$ & $\begin{array}{c}0.036 \\
(0.836)\end{array}$ \\
\hline $\begin{array}{l}\text { Father's education } \\
\text { - Secondary } \\
\text { School }\end{array}$ & $\begin{array}{l}-0.018 \\
(0.735)\end{array}$ & $\begin{array}{c}0.039 \\
(0.531)\end{array}$ & $\begin{array}{c}0.074 \\
(0.185)\end{array}$ & $\begin{array}{l}-0.019 \\
(0.547)\end{array}$ & $\begin{array}{l}-0.015 \\
(0.818)\end{array}$ & $\begin{array}{l}-0.091^{*} \\
(0.084)\end{array}$ & $\begin{array}{l}-0.024 \\
(0.445)\end{array}$ & $\begin{array}{l}-0.037 \\
(0.815)\end{array}$ \\
\hline $\begin{array}{l}\text { Father's education } \\
\text { - Higher education }\end{array}$ & $\begin{array}{l}-0.020 \\
(0.720)\end{array}$ & $\begin{array}{c}0.002 \\
(0.972)\end{array}$ & $\begin{array}{c}0.043 \\
(0.538)\end{array}$ & $\begin{array}{l}-0.025 \\
(0.583)\end{array}$ & $\begin{array}{l}-0.080 \\
(0.299)\end{array}$ & $\begin{array}{l}-0.086 \\
(0.215)\end{array}$ & $\begin{array}{l}-0.061^{*} \\
(0.065)\end{array}$ & $\begin{array}{l}-0.184 \\
(0.266)\end{array}$ \\
\hline $\begin{array}{l}\text { Mother's } \\
\text { education - } \\
\text { Secondary School }\end{array}$ & $\begin{array}{c}0.036 \\
(0.367)\end{array}$ & $\begin{array}{l}-0.038 \\
(0.271)\end{array}$ & $\begin{array}{l}-0.004 \\
(0.902)\end{array}$ & $\begin{array}{c}0.040 \\
(0.159)\end{array}$ & $\begin{array}{c}0.044 \\
(0.448)\end{array}$ & $\begin{array}{c}0.010 \\
(0.721)\end{array}$ & $\begin{array}{l}-0.013 \\
(0.533)\end{array}$ & $\begin{array}{c}0.070 \\
(0.367)\end{array}$ \\
\hline $\begin{array}{l}\text { Mother's } \\
\text { education - Higher } \\
\text { education }\end{array}$ & $\begin{array}{c}0.042 \\
(0.602)\end{array}$ & $\begin{array}{l}-0.015 \\
(0.861)\end{array}$ & $\begin{array}{c}0.022 \\
(0.786)\end{array}$ & $\begin{array}{c}0.077 \\
(0.223)\end{array}$ & $\begin{array}{l}-0.031 \\
(0.586)\end{array}$ & $\begin{array}{c}0.097 \\
(0.369)\end{array}$ & $\begin{array}{c}0.042 \\
(0.163)\end{array}$ & $\begin{array}{l}0.115 \\
(0.571)\end{array}$ \\
\hline $\begin{array}{l}\text { Single parent, age } \\
15\end{array}$ & $\begin{array}{c}0.079 \\
(0.286)\end{array}$ & $\begin{array}{c}0.038 \\
(0.509)\end{array}$ & $\begin{array}{l}0.100^{*} \\
(0.078)\end{array}$ & $\begin{array}{c}0.075 \\
(0.198)\end{array}$ & $\begin{array}{l}0.155^{\star * *} \\
(0.005)\end{array}$ & $\begin{array}{l}0.154^{* *} \\
(0.046)\end{array}$ & $\begin{array}{c}0.028 \\
(0.313)\end{array}$ & $\begin{array}{l}0.374^{* *} \\
(0.023)\end{array}$ \\
\hline $\begin{array}{l}\text { Child has older } \\
\text { siblings }\end{array}$ & $\begin{array}{c}0.010 \\
(0.757)\end{array}$ & $\begin{array}{c}0.044 \\
(0.310)\end{array}$ & $\begin{array}{c}0.054 \\
(0.197)\end{array}$ & $\begin{array}{c}0.028 \\
(0.391)\end{array}$ & $\begin{array}{l}-0.037 \\
(0.279)\end{array}$ & $\begin{array}{l}-0.003 \\
(0.966)\end{array}$ & $\begin{array}{l}-0.011 \\
(0.507)\end{array}$ & $\begin{array}{c}0.034 \\
(0.725)\end{array}$ \\
\hline $\begin{array}{l}\text { Number of } \\
\text { siblings, age } 15\end{array}$ & $\begin{array}{l}-0.013 \\
(0.379)\end{array}$ & $\begin{array}{l}-0.021 \\
(0.250)\end{array}$ & $\begin{array}{l}-0.012 \\
(0.603)\end{array}$ & $\begin{array}{c}0.012 \\
(0.318)\end{array}$ & $\begin{array}{l}-0.006 \\
(0.719)\end{array}$ & $\begin{array}{c}0.039 \\
(0.130)\end{array}$ & $\begin{array}{c}0.021 \\
(0.107)\end{array}$ & $\begin{array}{l}-0.008 \\
(0.834)\end{array}$ \\
\hline $\begin{array}{l}\text { Chils is enrolled, } \\
\text { age } 15\end{array}$ & $\begin{array}{l}-0.054 \\
(0.599)\end{array}$ & $\begin{array}{l}-0.040 \\
(0.734)\end{array}$ & $\begin{array}{l}-0.093 \\
(0.364)\end{array}$ & $\begin{array}{c}0.015 \\
(0.878)\end{array}$ & $\begin{array}{l}-0.017 \\
(0.828)\end{array}$ & $\begin{array}{l}-0.195 \\
(0.120)\end{array}$ & $\begin{array}{l}-0.042 \\
(0.683)\end{array}$ & $\begin{array}{l}-0.137 \\
(0.566)\end{array}$ \\
\hline $\begin{array}{l}\text { PPVT z-score, age } \\
15\end{array}$ & $\begin{array}{l}-0.043 \\
(0.132)\end{array}$ & $\begin{array}{l}-0.042 \\
(0.346)\end{array}$ & $\begin{array}{l}-0.018 \\
(0.623)\end{array}$ & $\begin{array}{l}-0.034 \\
(0.290)\end{array}$ & $\begin{array}{c}0.039 \\
(0.257)\end{array}$ & $\begin{array}{l}-0.025 \\
(0.660)\end{array}$ & $\begin{array}{c}0.011 \\
(0.534)\end{array}$ & $\begin{array}{l}-0.069 \\
(0.478)\end{array}$ \\
\hline $\begin{array}{l}\text { Math z-score, age } \\
15\end{array}$ & $\begin{array}{c}0.013 \\
(0.520)\end{array}$ & $\begin{array}{c}0.005 \\
(0.745)\end{array}$ & $\begin{array}{l}-0.016 \\
(0.439)\end{array}$ & $\begin{array}{l}-0.014 \\
(0.512)\end{array}$ & $\begin{array}{l}-0.014 \\
(0.634)\end{array}$ & $\begin{array}{c}0.000 \\
(0.998)\end{array}$ & $\begin{array}{l}-0.012 \\
(0.359)\end{array}$ & $\begin{array}{l}-0.021 \\
(0.641)\end{array}$ \\
\hline $\begin{array}{l}\text { Number of } \\
\text { observations }\end{array}$ & 471 & 471 & 471 & 471 & 471 & 471 & 471 & 471 \\
\hline R-squared & 0.204 & 0.182 & 0.183 & 0.131 & 0.115 & 0.124 & 0.106 & 0.172 \\
\hline
\end{tabular}

Note: The table reports the estimates of the linear probability model with standard errors (in parentheses) clustered at cluster level, ${ }^{*} \mathrm{p}<0.1{ }^{* *} \mathrm{p}<0.05{ }^{* * *}$ $p<0.1$. All controls were included as reported together with dummy variables for the cluster that individuals were recruited in the 2002 round; coefficients $\mathrm{p}<0.1$. All controls were includ
for these are not reported. 
Table 9. Early social competencies and other predictors of the participation in risky behaviours at age 19

\begin{tabular}{|c|c|c|c|c|c|c|c|c|}
\hline & Smoking & Drinking & \begin{tabular}{|c} 
Drinking \& \\
violence
\end{tabular} & $\begin{array}{c}\text { Drugs } \\
\text { consumption }\end{array}$ & $\begin{array}{l}\text { Unprotected } \\
\text { sex }\end{array}$ & $\begin{array}{c}\text { Criminal } \\
\text { beh. }\end{array}$ & $\begin{array}{c}\text { Carried a } \\
\text { weapon }\end{array}$ & $\begin{array}{c}\text { No. of } \\
\text { risky beh. }\end{array}$ \\
\hline $\begin{array}{l}\text { Agency index, age } \\
12\end{array}$ & $\begin{array}{c}0.037^{\star} \\
(0.089)\end{array}$ & $\begin{array}{l}-0.021 \\
(0.473)\end{array}$ & $\begin{array}{c}0.012 \\
(0.726)\end{array}$ & $\begin{array}{c}0.006 \\
(0.852)\end{array}$ & $\begin{array}{c}0.052^{*} \\
(0.099)\end{array}$ & $\begin{array}{c}0.022 \\
(0.332)\end{array}$ & $\begin{array}{c}0.005 \\
(0.743)\end{array}$ & $\begin{array}{c}0.078 \\
(0.201)\end{array}$ \\
\hline $\begin{array}{l}\text { Pride index, age } \\
12\end{array}$ & $\begin{array}{l}-0.016 \\
(0.573)\end{array}$ & $\begin{array}{l}-0.021 \\
(0.452)\end{array}$ & $\begin{array}{l}-0.050 \\
(0.148)\end{array}$ & $\begin{array}{l}-0.037^{*} \\
(0.090)\end{array}$ & $\begin{array}{l}-0.082^{*} \\
(0.052)\end{array}$ & $\begin{array}{l}-0.015 \\
(0.577)\end{array}$ & $\begin{array}{l}-0.022^{*} \\
(0.061)\end{array}$ & $\begin{array}{l}-0.177^{\star *} \\
(0.025)\end{array}$ \\
\hline Child is male & $\begin{array}{l}0.229^{* * *} \\
(0.000)\end{array}$ & $\begin{array}{l}0.231^{* * *} \\
(0.000)\end{array}$ & $\begin{array}{l}0.259^{* * *} \\
(0.000)\end{array}$ & $\begin{array}{l}0.120^{* * *} \\
(0.001)\end{array}$ & $\begin{array}{l}-0.019 \\
(0.682)\end{array}$ & $\begin{array}{l}0.108^{* *} \\
(0.017)\end{array}$ & $\begin{array}{r}0.009 \\
(0.651)\end{array}$ & $\begin{array}{l}0.569^{* * *} \\
(0.000)\end{array}$ \\
\hline Age in $\mathrm{R} 4$ & $\begin{array}{l}0.107^{* * *} \\
(0.008)\end{array}$ & $\begin{array}{l}0.129^{* *} \\
(0.014)\end{array}$ & $\begin{array}{l}0.123^{\star *} \\
(0.011)\end{array}$ & $\begin{array}{l}0.054^{\star *} \\
(0.031)\end{array}$ & $\begin{array}{l}-0.009 \\
(0.858)\end{array}$ & $\begin{array}{l}-0.005 \\
(0.894)\end{array}$ & $\begin{array}{l}-0.016 \\
(0.480)\end{array}$ & $\begin{array}{l}0.264^{\star *} \\
(0.023)\end{array}$ \\
\hline $\begin{array}{l}\text { Type site - Rural, } \\
\text { age } 8\end{array}$ & $\begin{array}{l}-0.057 \\
(0.244)\end{array}$ & $\begin{array}{l}-0.135 \\
(0.268)\end{array}$ & $\begin{array}{l}-0.139 \\
(0.189)\end{array}$ & $\begin{array}{c}0.047 \\
(0.382)\end{array}$ & $\begin{array}{c}0.030 \\
(0.780)\end{array}$ & $\begin{array}{l}-0.001 \\
(0.987)\end{array}$ & $\begin{array}{l}-0.058 \\
(0.244)\end{array}$ & $\begin{array}{l}-0.173 \\
(0.307)\end{array}$ \\
\hline $\begin{array}{l}\text { Migrated between } \\
\text { age } 8 \text { and } 15\end{array}$ & $\begin{array}{c}0.028 \\
(0.643)\end{array}$ & $\begin{array}{c}0.123 \\
(0.145)\end{array}$ & $\begin{array}{c}0.129 \\
(0.125)\end{array}$ & $\begin{array}{c}0.064 \\
(0.253)\end{array}$ & $\begin{array}{r}0.125^{*} \\
(0.071)\end{array}$ & $\begin{array}{c}0.028 \\
(0.660)\end{array}$ & $\begin{array}{l}-0.026 \\
(0.483)\end{array}$ & $\begin{array}{l}0.314^{*} \\
(0.087)\end{array}$ \\
\hline $\begin{array}{l}\text { Second tercile of } \\
\text { wealth, age } 8\end{array}$ & $\begin{array}{c}0.007 \\
(0.848)\end{array}$ & $\begin{array}{l}0.111^{* *} \\
(0.043)\end{array}$ & $\begin{array}{c}0.091 \\
(0.111)\end{array}$ & $\begin{array}{c}0.044 \\
(0.170)\end{array}$ & $\begin{array}{c}0.006 \\
(0.880)\end{array}$ & $\begin{array}{l}-0.004 \\
(0.952)\end{array}$ & $\begin{array}{l}-0.005 \\
(0.826)\end{array}$ & $\begin{array}{l}0.163^{*} \\
(0.094)\end{array}$ \\
\hline $\begin{array}{l}\text { Third tercile of } \\
\text { wealth, age } 8\end{array}$ & $\begin{array}{c}0.010 \\
(0.827)\end{array}$ & $\begin{array}{c}0.065 \\
(0.226)\end{array}$ & $\begin{array}{c}0.071 \\
(0.208)\end{array}$ & $\begin{array}{l}0.094^{* *} \\
(0.031)\end{array}$ & $\begin{array}{c}0.062 \\
(0.169)\end{array}$ & $\begin{array}{l}-0.037 \\
(0.605)\end{array}$ & $\begin{array}{l}-0.026 \\
(0.333)\end{array}$ & $\begin{array}{r}0.205^{*} \\
(0.076)\end{array}$ \\
\hline $\begin{array}{l}\text { Father's education } \\
\text { - Secondary } \\
\text { School }\end{array}$ & $\begin{array}{l}-0.013 \\
(0.796)\end{array}$ & $\begin{array}{c}0.025 \\
(0.679)\end{array}$ & $\begin{array}{c}0.062 \\
(0.240)\end{array}$ & $\begin{array}{l}-0.015 \\
(0.651)\end{array}$ & $\begin{array}{l}-0.003 \\
(0.953)\end{array}$ & $\begin{array}{l}-0.106^{*} \\
(0.078)\end{array}$ & $\begin{array}{l}-0.026 \\
(0.335)\end{array}$ & $\begin{array}{l}-0.033 \\
(0.830)\end{array}$ \\
\hline $\begin{array}{l}\text { Father's education } \\
\text { - Higher education }\end{array}$ & $\begin{array}{l}-0.039 \\
(0.427)\end{array}$ & $\begin{array}{l}-0.022 \\
(0.723)\end{array}$ & $\begin{array}{c}0.017 \\
(0.815)\end{array}$ & $\begin{array}{l}-0.038 \\
(0.383)\end{array}$ & $\begin{array}{l}-0.041 \\
(0.545)\end{array}$ & $\begin{array}{l}-0.104^{*} \\
(0.053)\end{array}$ & $\begin{array}{l}-0.057^{* *} \\
(0.040)\end{array}$ & $\begin{array}{l}-0.197 \\
(0.177)\end{array}$ \\
\hline $\begin{array}{l}\text { Mother's } \\
\text { education - } \\
\text { Secondary School }\end{array}$ & $\begin{array}{c}0.018 \\
(0.684)\end{array}$ & $\begin{array}{l}-0.051 \\
(0.152)\end{array}$ & $\begin{array}{l}-0.004 \\
(0.898)\end{array}$ & $\begin{array}{c}0.023 \\
(0.437)\end{array}$ & $\begin{array}{c}0.011 \\
(0.844)\end{array}$ & $\begin{array}{l}-0.022 \\
(0.566)\end{array}$ & $\begin{array}{l}-0.022 \\
(0.281)\end{array}$ & $\begin{array}{l}-0.020 \\
(0.797)\end{array}$ \\
\hline $\begin{array}{l}\text { Mother's } \\
\text { education - Higher } \\
\text { education }\end{array}$ & $\begin{array}{c}0.001 \\
(0.991)\end{array}$ & $\begin{array}{l}-0.024 \\
(0.779)\end{array}$ & $\begin{array}{c}0.013 \\
(0.892)\end{array}$ & $\begin{array}{c}0.005 \\
(0.941)\end{array}$ & $\begin{array}{l}-0.031 \\
(0.575)\end{array}$ & $\begin{array}{c}0.053 \\
(0.629)\end{array}$ & $\begin{array}{c}0.030 \\
(0.278)\end{array}$ & $\begin{array}{l}-0.018 \\
(0.935)\end{array}$ \\
\hline $\begin{array}{l}\text { Single parent, age } \\
8\end{array}$ & $\begin{array}{c}0.055 \\
(0.374)\end{array}$ & $\begin{array}{l}-0.021 \\
(0.663)\end{array}$ & $\begin{array}{l}-0.013 \\
(0.832)\end{array}$ & $\begin{array}{c}0.080 \\
(0.159)\end{array}$ & $\begin{array}{c}0.084 \\
(0.236)\end{array}$ & $\begin{array}{c}0.102 \\
(0.309)\end{array}$ & $\begin{array}{c}0.014 \\
(0.638)\end{array}$ & $\begin{array}{c}0.214 \\
(0.287)\end{array}$ \\
\hline $\begin{array}{l}\text { Child has older } \\
\text { siblings }\end{array}$ & $\begin{array}{c}0.014 \\
(0.605)\end{array}$ & $\begin{array}{c}0.039 \\
(0.392)\end{array}$ & $\begin{array}{c}0.060 \\
(0.215)\end{array}$ & $\begin{array}{c}0.008 \\
(0.809)\end{array}$ & $\begin{array}{l}-0.008 \\
(0.796)\end{array}$ & $\begin{array}{l}-0.007 \\
(0.905)\end{array}$ & $\begin{array}{l}-0.015 \\
(0.266)\end{array}$ & $\begin{array}{c}0.038 \\
(0.683)\end{array}$ \\
\hline $\begin{array}{l}\text { Number of } \\
\text { siblings, age } 8\end{array}$ & $\begin{array}{l}-0.016 \\
(0.272)\end{array}$ & $\begin{array}{l}-0.027 \\
(0.100)\end{array}$ & $\begin{array}{l}-0.033^{*} \\
(0.079)\end{array}$ & $\begin{array}{c}0.001 \\
(0.954)\end{array}$ & $\begin{array}{l}-0.005 \\
(0.755)\end{array}$ & $\begin{array}{c}0.017 \\
(0.452)\end{array}$ & $\begin{array}{c}0.008 \\
(0.518)\end{array}$ & $\begin{array}{l}-0.040 \\
(0.299)\end{array}$ \\
\hline $\begin{array}{l}\text { Child started } \\
\text { school late }\end{array}$ & $\begin{array}{c}0.076 \\
(0.338)\end{array}$ & $\begin{array}{c}0.074 \\
(0.271)\end{array}$ & $\begin{array}{l}0.124^{\star *} \\
(0.042)\end{array}$ & $\begin{array}{l}0.121^{\text {** }} \\
(0.031)\end{array}$ & $\begin{array}{c}0.003 \\
(0.966)\end{array}$ & $\begin{array}{c}0.147 \\
(0.161)\end{array}$ & $\begin{array}{c}0.047 \\
(0.325)\end{array}$ & $\begin{array}{c}0.321 \\
(0.121)\end{array}$ \\
\hline $\begin{array}{l}\text { Standardised } \\
\text { values of Raven, } \\
\text { age } 8\end{array}$ & $\begin{array}{l}-0.008 \\
(0.721)\end{array}$ & $\begin{array}{l}-0.000 \\
(0.982)\end{array}$ & $\begin{array}{l}-0.005 \\
(0.791)\end{array}$ & $\begin{array}{c}0.011 \\
(0.534)\end{array}$ & $\begin{array}{l}-0.002 \\
(0.936)\end{array}$ & $\begin{array}{c}0.036 \\
(0.276)\end{array}$ & $\begin{array}{l}-0.001 \\
(0.946)\end{array}$ & $\begin{array}{c}0.001 \\
(0.988)\end{array}$ \\
\hline $\begin{array}{l}\text { Number of } \\
\text { observations }\end{array}$ & 509 & 509 & 509 & 509 & 509 & 509 & 509 & 509 \\
\hline R-squared & 0.166 & 0.167 & 0.179 & 0.120 & 0.106 & 0.078 & 0.075 & 0.164 \\
\hline
\end{tabular}

Note: The table reports the estimates of the linear probability model with standard errors (in parentheses) clustered at cluster level, ${ }^{*} p<0.1{ }^{* *} p<0.05$ ${ }^{* * *} p<0.1$. All controls were included as reported together with dummy variables for the cluster that individuals were recruited in the 2002 round; coefficients for these are not reported 
Table 10. Early educational aspirations and other predictors of the participation in risky behaviours at age 19

\begin{tabular}{|c|c|c|c|c|c|c|c|c|}
\hline & Smoking & Drinking & $\begin{array}{l}\text { Drinking \& } \\
\text { violence }\end{array}$ & $\begin{array}{c}\text { Drugs } \\
\text { consumption }\end{array}$ & $\begin{array}{l}\text { Unprotected } \\
\text { sex. }\end{array}$ & $\begin{array}{c}\text { Criminal } \\
\text { beh. }\end{array}$ & $\begin{array}{l}\text { Carried a } \\
\text { weapon }\end{array}$ & $\begin{array}{c}\text { No. of } \\
\text { risky beh. }\end{array}$ \\
\hline $\begin{array}{l}\text { Child aspired for } \\
\text { higher education, } \\
\text { age } 12\end{array}$ & $\begin{array}{l}-0.101 \\
(0.183)\end{array}$ & $\begin{array}{l}-0.011 \\
(0.806)\end{array}$ & $\begin{array}{c}0.020 \\
(0.718)\end{array}$ & $\begin{array}{l}-0.070 \\
(0.290)\end{array}$ & $\begin{array}{l}-0.012 \\
(0.880)\end{array}$ & $\begin{array}{l}-0.128^{* * *} \\
(0.004)\end{array}$ & $\begin{array}{l}-0.272^{\star *} \\
(0.044)\end{array}$ & $\begin{array}{l}-0.322^{*} \\
(0.069)\end{array}$ \\
\hline Child is male & $\begin{array}{l}0.224^{* * *} \\
(0.000)\end{array}$ & $\begin{array}{l}0.230^{* * *} \\
(0.000)\end{array}$ & $\begin{array}{l}0.254^{\star \star \star} \\
(0.000)\end{array}$ & $\begin{array}{l}0.116^{\star * \star} \\
(0.001)\end{array}$ & $\begin{array}{l}-0.028 \\
(0.550)\end{array}$ & $\begin{array}{c}0.004 \\
(0.821)\end{array}$ & $\begin{array}{l}0.101^{* *} \\
(0.015)\end{array}$ & $\begin{array}{l}0.545^{\star \star *} \\
(0.000)\end{array}$ \\
\hline Age in $\mathrm{R} 4$ & $\begin{array}{l}0.103^{* *} \\
(0.013)\end{array}$ & $\begin{array}{l}0.129^{\star *} \\
(0.013)\end{array}$ & $\begin{array}{l}0.120^{* *} \\
(0.012)\end{array}$ & $\begin{array}{l}0.051^{* *} \\
(0.047)\end{array}$ & $\begin{array}{l}-0.015 \\
(0.763)\end{array}$ & $\begin{array}{l}-0.019 \\
(0.394)\end{array}$ & $\begin{array}{l}-0.011 \\
(0.782)\end{array}$ & $\begin{array}{l}0.248^{* *} \\
(0.039)\end{array}$ \\
\hline $\begin{array}{l}\text { Type site - Rural, } \\
\text { age } 8\end{array}$ & $\begin{array}{l}-0.058 \\
(0.207)\end{array}$ & $\begin{array}{l}-0.142 \\
(0.240)\end{array}$ & $\begin{array}{l}-0.154 \\
(0.131)\end{array}$ & $\begin{array}{c}0.037 \\
(0.485)\end{array}$ & $\begin{array}{c}0.008 \\
(0.937)\end{array}$ & $\begin{array}{l}-0.061 \\
(0.198)\end{array}$ & $\begin{array}{c}0.001 \\
(0.987)\end{array}$ & $\begin{array}{l}-0.216^{*} \\
(0.095)\end{array}$ \\
\hline $\begin{array}{l}\text { Migrated between } \\
\text { age } 8 \text { and } 15\end{array}$ & $\begin{array}{c}0.043 \\
(0.431)\end{array}$ & $\begin{array}{c}0.125 \\
(0.138)\end{array}$ & $\begin{array}{l}0.137^{*} \\
(0.090)\end{array}$ & $\begin{array}{c}0.075 \\
(0.161)\end{array}$ & $\begin{array}{l}0.146^{* *} \\
(0.029)\end{array}$ & $\begin{array}{l}-0.012 \\
(0.761)\end{array}$ & $\begin{array}{c}0.054 \\
(0.435)\end{array}$ & $\begin{array}{l}0.377^{* *} \\
(0.022)\end{array}$ \\
\hline $\begin{array}{l}\text { Second tercile of } \\
\text { wealth, age } 8\end{array}$ & $\begin{array}{c}0.009 \\
(0.825)\end{array}$ & $\begin{array}{l}0.112^{\star *} \\
(0.038)\end{array}$ & $\begin{array}{c}0.087 \\
(0.130)\end{array}$ & $\begin{array}{c}0.045 \\
(0.193)\end{array}$ & $\begin{array}{l}-0.000 \\
(0.999)\end{array}$ & $\begin{array}{l}-0.002 \\
(0.947)\end{array}$ & $\begin{array}{c}0.005 \\
(0.944)\end{array}$ & $\begin{array}{c}0.164 \\
(0.107)\end{array}$ \\
\hline $\begin{array}{l}\text { Third tercile of } \\
\text { wealth, age } 8\end{array}$ & $\begin{array}{c}0.015 \\
(0.746)\end{array}$ & $\begin{array}{c}0.064 \\
(0.219)\end{array}$ & $\begin{array}{c}0.068 \\
(0.219)\end{array}$ & $\begin{array}{l}0.096^{\star *} \\
(0.028)\end{array}$ & $\begin{array}{c}0.059 \\
(0.198)\end{array}$ & $\begin{array}{l}-0.020 \\
(0.426)\end{array}$ & $\begin{array}{l}-0.023 \\
(0.757)\end{array}$ & $\begin{array}{l}0.214^{*} \\
(0.053)\end{array}$ \\
\hline $\begin{array}{l}\text { Father's education } \\
\text { - Secondary } \\
\text { School }\end{array}$ & $\begin{array}{l}-0.007 \\
(0.898)\end{array}$ & $\begin{array}{c}0.024 \\
(0.689)\end{array}$ & $\begin{array}{l}0.057 \\
(0.291)\end{array}$ & $\begin{array}{l}-0.013 \\
(0.700)\end{array}$ & $\begin{array}{l}-0.009 \\
(0.877)\end{array}$ & $\begin{array}{l}-0.019 \\
(0.487)\end{array}$ & $\begin{array}{l}-0.087 \\
(0.131)\end{array}$ & $\begin{array}{l}-0.024 \\
(0.885)\end{array}$ \\
\hline $\begin{array}{l}\text { Father's education } \\
\text { - Higher education }\end{array}$ & $\begin{array}{l}-0.034 \\
(0.506)\end{array}$ & $\begin{array}{l}-0.027 \\
(0.670)\end{array}$ & $\begin{array}{c}0.009 \\
(0.908)\end{array}$ & $\begin{array}{l}-0.041 \\
(0.325)\end{array}$ & $\begin{array}{l}-0.051 \\
(0.455)\end{array}$ & $\begin{array}{l}-0.056^{*} \\
(0.054)\end{array}$ & $\begin{array}{l}-0.093^{*} \\
(0.094)\end{array}$ & $\begin{array}{l}-0.209 \\
(0.149)\end{array}$ \\
\hline $\begin{array}{l}\text { Mother's } \\
\text { education - } \\
\text { Secondary School }\end{array}$ & $\begin{array}{c}0.018 \\
(0.684)\end{array}$ & $\begin{array}{l}-0.050 \\
(0.154)\end{array}$ & $\begin{array}{l}-0.005 \\
(0.892)\end{array}$ & $\begin{array}{c}0.023 \\
(0.445)\end{array}$ & $\begin{array}{c}0.010 \\
(0.859)\end{array}$ & $\begin{array}{l}-0.021 \\
(0.224)\end{array}$ & $\begin{array}{l}-0.021 \\
(0.547)\end{array}$ & $\begin{array}{l}-0.020 \\
(0.800)\end{array}$ \\
\hline $\begin{array}{l}\text { Mother's } \\
\text { education - Higher } \\
\text { education }\end{array}$ & $\begin{array}{l}-0.001 \\
(0.986)\end{array}$ & $\begin{array}{l}-0.023 \\
(0.788)\end{array}$ & $\begin{array}{c}0.009 \\
(0.921)\end{array}$ & $\begin{array}{c}0.004 \\
(0.955)\end{array}$ & $\begin{array}{l}-0.038 \\
(0.477)\end{array}$ & $\begin{array}{c}0.030 \\
(0.281)\end{array}$ & $\begin{array}{c}0.054 \\
(0.627)\end{array}$ & $\begin{array}{l}-0.029 \\
(0.898)\end{array}$ \\
\hline $\begin{array}{l}\text { Single parent, age } \\
8\end{array}$ & $\begin{array}{c}0.051 \\
(0.387)\end{array}$ & $\begin{array}{l}-0.021 \\
(0.660)\end{array}$ & $\begin{array}{l}-0.009 \\
(0.882)\end{array}$ & $\begin{array}{c}0.078 \\
(0.168)\end{array}$ & $\begin{array}{c}0.089 \\
(0.181)\end{array}$ & $\begin{array}{c}0.009 \\
(0.770)\end{array}$ & $\begin{array}{c}0.089 \\
(0.356)\end{array}$ & $\begin{array}{c}0.207 \\
(0.283)\end{array}$ \\
\hline $\begin{array}{l}\text { Child has older } \\
\text { siblings }\end{array}$ & $\begin{array}{c}0.014 \\
(0.627)\end{array}$ & $\begin{array}{c}0.038 \\
(0.396)\end{array}$ & $\begin{array}{c}0.056 \\
(0.230)\end{array}$ & $\begin{array}{c}0.006 \\
(0.845)\end{array}$ & $\begin{array}{l}-0.014 \\
(0.656)\end{array}$ & $\begin{array}{l}-0.015 \\
(0.239)\end{array}$ & $\begin{array}{l}-0.005 \\
(0.930)\end{array}$ & $\begin{array}{c}0.030 \\
(0.744)\end{array}$ \\
\hline $\begin{array}{l}\text { Number of } \\
\text { siblings, age } 8\end{array}$ & $\begin{array}{l}-0.015 \\
(0.294)\end{array}$ & $\begin{array}{l}-0.026 \\
(0.116)\end{array}$ & $\begin{array}{l}-0.030 \\
(0.112)\end{array}$ & $\begin{array}{c}0.002 \\
(0.809)\end{array}$ & $\begin{array}{l}-0.001 \\
(0.953)\end{array}$ & $\begin{array}{c}0.009 \\
(0.470)\end{array}$ & $\begin{array}{c}0.018 \\
(0.417)\end{array}$ & $\begin{array}{l}-0.031 \\
(0.409)\end{array}$ \\
\hline $\begin{array}{l}\text { Child started } \\
\text { school late }\end{array}$ & $\begin{array}{c}0.062 \\
(0.419)\end{array}$ & $\begin{array}{c}0.077 \\
(0.254)\end{array}$ & $\begin{array}{l}0.136^{\star *} \\
(0.022)\end{array}$ & $\begin{array}{l}0.117^{\star \star} \\
(0.031)\end{array}$ & $\begin{array}{c}0.016 \\
(0.843)\end{array}$ & $\begin{array}{c}0.031 \\
(0.492)\end{array}$ & $\begin{array}{c}0.107 \\
(0.257)\end{array}$ & $\begin{array}{c}0.303 \\
(0.127)\end{array}$ \\
\hline $\begin{array}{l}\text { Standardized } \\
\text { values of (raven), } \\
\text { age } 8\end{array}$ & $\begin{array}{l}-0.005 \\
(0.804)\end{array}$ & $\begin{array}{l}-0.002 \\
(0.932)\end{array}$ & $\begin{array}{l}-0.004 \\
(0.843)\end{array}$ & $\begin{array}{c}0.012 \\
(0.498)\end{array}$ & $\begin{array}{c}0.002 \\
(0.906)\end{array}$ & $\begin{array}{l}-0.001 \\
(0.966)\end{array}$ & $\begin{array}{c}0.037 \\
(0.242)\end{array}$ & $\begin{array}{c}0.007 \\
(0.885)\end{array}$ \\
\hline $\begin{array}{l}\text { Number of } \\
\text { observations }\end{array}$ & 509 & 509 & 509 & 509 & 509 & 509 & 509 & 509 \\
\hline R-squared & 0.168 & 0.166 & 0.176 & 0.119 & 0.094 & 0.092 & 0.093 & 0.160 \\
\hline
\end{tabular}

Note: The table reports the estimates of the linear probability model with standard errors (in parentheses) clustered at cluster level, ${ }^{*} \mathrm{p}<0.1{ }^{* *} \mathrm{p}<0.05$ ${ }^{* * *} p<0.1$. All controls were included as reported together with dummy variables for the cluster that individuals were recruited in the 2002 round; coefficients for these are not reported. 
Table 11. Fixed-effects estimates of risky behaviours at age 19: including psychosocial competencies

\begin{tabular}{|c|c|c|c|c|c|c|c|}
\hline & Smoking & Drinking & $\begin{array}{l}\text { Drinking \& } \\
\text { violence }\end{array}$ & $\begin{array}{c}\text { Drugs } \\
\text { consumption }\end{array}$ & $\begin{array}{l}\text { Unprotected } \\
\text { sex. }\end{array}$ & $\begin{array}{l}\text { Carried a } \\
\text { weapon }\end{array}$ & $\begin{array}{l}\text { No. of risky } \\
\text { beh. }\end{array}$ \\
\hline Self-efficacy & $\begin{array}{l}-0.030 \\
(0.422)\end{array}$ & $\begin{array}{c}0.027 \\
(0.480)\end{array}$ & $\begin{array}{c}0.042 \\
(0.263)\end{array}$ & $\begin{array}{c}0.015 \\
(0.606)\end{array}$ & $\begin{array}{l}-0.026 \\
(0.467)\end{array}$ & $\begin{array}{l}-0.053^{* *} \\
(0.045)\end{array}$ & $\begin{array}{l}-0.068 \\
(0.456)\end{array}$ \\
\hline \multirow[t]{2}{*}{ Self-esteem } & $-0.048^{*}$ & $-0.096^{\star * *}$ & $-0.090^{* *}$ & -0.010 & 0.009 & -0.030 & $-0.174^{* *}$ \\
\hline & $(0.074)$ & $(0.003)$ & $(0.012)$ & (0.696) & (0.793) & $(0.204)$ & $(0.024)$ \\
\hline Type site - Rural & $\begin{array}{l}-0.259^{* * *} \\
(0.002)\end{array}$ & $\begin{array}{l}-0.581^{* * *} \\
(0.000)\end{array}$ & $\begin{array}{l}-0.718^{* * *} \\
(0.000)\end{array}$ & $\begin{array}{l}-0.246^{* * *} \\
(0.000)\end{array}$ & $\begin{array}{l}-0.338^{* * *} \\
(0.001)\end{array}$ & $\begin{array}{c}0.034 \\
(0.578)\end{array}$ & $\begin{array}{l}-1.391^{* * *} \\
(0.000)\end{array}$ \\
\hline $\begin{array}{l}\text { Migrated between } \\
\text { rounds }\end{array}$ & $\begin{array}{l}0.150^{\star *} \\
(0.022)\end{array}$ & $\begin{array}{l}0.276^{* * *} \\
(0.000)\end{array}$ & $\begin{array}{l}0.359^{* * *} \\
(0.000)\end{array}$ & $\begin{array}{l}0.096^{*} \\
(0.059)\end{array}$ & $\begin{array}{c}0.131 \\
(0.107)\end{array}$ & $\begin{array}{l}-0.038 \\
(0.503)\end{array}$ & $\begin{array}{l}0.616^{* * *} \\
(0.001)\end{array}$ \\
\hline $\begin{array}{l}\text { Wealth tercile : } \\
\text { middle }\end{array}$ & $\begin{array}{l}-0.047 \\
(0.410)\end{array}$ & $\begin{array}{l}0.050 \\
(0.410)\end{array}$ & $\begin{array}{l}0.012 \\
(0.853)\end{array}$ & $\begin{array}{l}-0.023 \\
(0.465)\end{array}$ & $\begin{array}{l}0.048 \\
(0.450)\end{array}$ & $\begin{array}{l}0.018 \\
(0.659)\end{array}$ & $\begin{array}{c}0.046 \\
(0.735)\end{array}$ \\
\hline Wealth tercile: top & $\begin{array}{l}-0.132^{*} \\
(0.057)\end{array}$ & $\begin{array}{c}0.085 \\
(0.280)\end{array}$ & $\begin{array}{c}0.012 \\
(0.887)\end{array}$ & $\begin{array}{l}-0.087^{* *} \\
(0.044)\end{array}$ & $\begin{array}{c}0.022 \\
(0.791)\end{array}$ & $\begin{array}{l}-0.007 \\
(0.888)\end{array}$ & $\begin{array}{l}-0.120 \\
(0.488)\end{array}$ \\
\hline Single parent & $\begin{array}{c}0.079 \\
(0.264)\end{array}$ & $\begin{array}{c}0.139 \\
(0.111)\end{array}$ & $\begin{array}{l}0.193^{\star \star} \\
(0.025)\end{array}$ & $\begin{array}{c}0.044 \\
(0.277)\end{array}$ & $\begin{array}{l}0.133^{*} \\
(0.092)\end{array}$ & $\begin{array}{l}0.029 \\
(0.261)\end{array}$ & $\begin{array}{l}0.424^{\star *} \\
(0.018)\end{array}$ \\
\hline Number of siblings & $\begin{array}{l}-0.011 \\
(0.547)\end{array}$ & $\begin{array}{l}-0.011 \\
(0.610)\end{array}$ & $\begin{array}{l}-0.009 \\
(0.708)\end{array}$ & $\begin{array}{c}0.002 \\
(0.910)\end{array}$ & $\begin{array}{l}-0.043^{*} \\
(0.064)\end{array}$ & $\begin{array}{c}0.000 \\
(0.972)\end{array}$ & $\begin{array}{l}-0.063 \\
(0.250)\end{array}$ \\
\hline Child is enrolled & $\begin{array}{l}-0.095 \\
(0.222)\end{array}$ & $\begin{array}{l}-0.210^{* *} \\
(0.046)\end{array}$ & $\begin{array}{l}-0.160 \\
(0.157)\end{array}$ & $\begin{array}{l}-0.148^{*} \\
(0.086)\end{array}$ & $\begin{array}{l}-0.256^{* *} \\
(0.013)\end{array}$ & $\begin{array}{c}0.110 \\
(0.231)\end{array}$ & $\begin{array}{l}-0.598^{* * *} \\
(0.006)\end{array}$ \\
\hline PPVT z-score & $\begin{array}{l}-0.029 \\
(0.247)\end{array}$ & $\begin{array}{l}-0.087^{* * *} \\
(0.007)\end{array}$ & $\begin{array}{l}-0.049 \\
(0.179)\end{array}$ & $\begin{array}{l}-0.049^{* * *} \\
(0.009)\end{array}$ & $\begin{array}{c}0.000 \\
(0.999)\end{array}$ & $\begin{array}{c}0.000 \\
(0.983)\end{array}$ & $\begin{array}{l}-0.166^{\star *} \\
(0.015)\end{array}$ \\
\hline Math z-score & $\begin{array}{l}-0.028 \\
(0.276)\end{array}$ & $\begin{array}{l}-0.068^{* *} \\
(0.015)\end{array}$ & $\begin{array}{l}-0.071^{\text {** }} \\
(0.016)\end{array}$ & $\begin{array}{c}0.018 \\
(0.376)\end{array}$ & $\begin{array}{l}-0.028 \\
(0.342)\end{array}$ & $\begin{array}{l}-0.020 \\
(0.269)\end{array}$ & $\begin{array}{l}-0.127^{*} \\
(0.071)\end{array}$ \\
\hline $\begin{array}{l}\text { Number of } \\
\text { observations }\end{array}$ & 872 & 872 & 872 & 872 & 872 & 872 & 872 \\
\hline R-squared & 0.064 & 0.139 & 0.156 & 0.074 & 0.097 & 0.033 & 0.168 \\
\hline
\end{tabular}

Note: The table reports the estimates for the individual fixed effects model, ${ }^{*} p<0.1^{* *} p<0.05{ }^{* * *} p<0.1$. All controls were included as reported. 
Table 12. Fixed-effects estimates of risky behaviours at age 19: including educational aspirations

\begin{tabular}{|c|c|c|c|c|c|c|c|}
\hline & Smoking & Drinking & $\begin{array}{l}\text { Drinking \& } \\
\text { violence }\end{array}$ & $\begin{array}{c}\text { Drugs } \\
\text { consumption }\end{array}$ & $\begin{array}{l}\text { Unprotected } \\
\text { sex. }\end{array}$ & $\begin{array}{l}\text { Carried a } \\
\text { weapon }\end{array}$ & $\begin{array}{c}\text { No. of risky } \\
\text { beh. }\end{array}$ \\
\hline $\begin{array}{l}\text { Child aspired for } \\
\text { higher education }\end{array}$ & $\begin{array}{c}0.071 \\
(0.367)\end{array}$ & $\begin{array}{c}0.060 \\
(0.459)\end{array}$ & $\begin{array}{l}0.041 \\
(0.641)\end{array}$ & $\begin{array}{c}0.028 \\
(0.682)\end{array}$ & $\begin{array}{l}-0.035 \\
(0.629)\end{array}$ & $\begin{array}{l}0.035 \\
(0.598)\end{array}$ & $\begin{array}{c}0.160 \\
(0.431)\end{array}$ \\
\hline Type site - Rural & $\begin{array}{l}-0.237^{* * *} \\
(0.002)\end{array}$ & $\begin{array}{l}-0.527^{* * *} \\
(0.000)\end{array}$ & $\begin{array}{l}-0.665^{* * *} \\
(0.000)\end{array}$ & $\begin{array}{l}-0.235^{* * *} \\
(0.000)\end{array}$ & $\begin{array}{l}-0.352^{* * *} \\
(0.000)\end{array}$ & $\begin{array}{c}0.040 \\
(0.520)\end{array}$ & $\begin{array}{l}-1.312^{* * *} \\
(0.000)\end{array}$ \\
\hline $\begin{array}{l}\text { Migrated between } \\
\text { rounds }\end{array}$ & $\begin{array}{l}0.141^{* *} \\
(0.025)\end{array}$ & $\begin{array}{l}0.248^{* * \star} \\
(0.002)\end{array}$ & $\begin{array}{l}0.331^{* * *} \\
(0.000)\end{array}$ & $\begin{array}{l}0.091^{*} \\
(0.068)\end{array}$ & $\begin{array}{l}0.138^{*} \\
(0.090)\end{array}$ & $\begin{array}{l}-0.038 \\
(0.501)\end{array}$ & $\begin{array}{l}0.579^{\star * *} \\
(0.003)\end{array}$ \\
\hline $\begin{array}{l}\text { Wealth tercile : } \\
\text { middle }\end{array}$ & $\begin{array}{l}-0.059 \\
(0.308)\end{array}$ & $\begin{array}{l}0.032 \\
(0.606)\end{array}$ & $\begin{array}{l}-0.004 \\
(0.952)\end{array}$ & $\begin{array}{l}-0.024 \\
(0.461)\end{array}$ & $\begin{array}{c}0.048 \\
(0.455)\end{array}$ & $\begin{array}{l}0.008 \\
(0.848)\end{array}$ & $\begin{array}{l}0.005 \\
(0.972)\end{array}$ \\
\hline Wealth tercile: top & $\begin{array}{l}-0.145^{\star *} \\
(0.038)\end{array}$ & $\begin{array}{c}0.070 \\
(0.379)\end{array}$ & $\begin{array}{l}0.001 \\
(0.995)\end{array}$ & $\begin{array}{l}-0.089^{\star *} \\
(0.046)\end{array}$ & $\begin{array}{c}0.024 \\
(0.779)\end{array}$ & $\begin{array}{l}-0.017 \\
(0.749)\end{array}$ & $\begin{array}{l}-0.157 \\
(0.379)\end{array}$ \\
\hline Single parent & $\begin{array}{c}0.073 \\
(0.314)\end{array}$ & $\begin{array}{l}0.135 \\
(0.124)\end{array}$ & $\begin{array}{l}0.191^{* *} \\
(0.026)\end{array}$ & $\begin{array}{c}0.044 \\
(0.275)\end{array}$ & $\begin{array}{l}0.133^{*} \\
(0.090)\end{array}$ & $\begin{array}{l}0.023 \\
(0.354)\end{array}$ & $\begin{array}{l}0.409^{* *} \\
(0.023)\end{array}$ \\
\hline Number of siblings & $\begin{array}{l}-0.012 \\
(0.519)\end{array}$ & $\begin{array}{l}-0.013 \\
(0.538)\end{array}$ & $\begin{array}{l}-0.011 \\
(0.640)\end{array}$ & $\begin{array}{c}0.001 \\
(0.936)\end{array}$ & $\begin{array}{l}-0.042^{*} \\
(0.069)\end{array}$ & $\begin{array}{c}0.000 \\
(0.974)\end{array}$ & $\begin{array}{l}-0.065 \\
(0.227)\end{array}$ \\
\hline Child is enrolled & $\begin{array}{l}-0.128 \\
(0.116)\end{array}$ & $\begin{array}{l}-0.229^{* *} \\
(0.045)\end{array}$ & $\begin{array}{l}-0.170 \\
(0.171)\end{array}$ & $\begin{array}{l}-0.151^{*} \\
(0.079)\end{array}$ & $\begin{array}{l}-0.255^{* *} \\
(0.013)\end{array}$ & $\begin{array}{c}0.081 \\
(0.386)\end{array}$ & $\begin{array}{l}-0.682^{* * *} \\
(0.004)\end{array}$ \\
\hline PPVT z-score & $\begin{array}{l}-0.026 \\
(0.307)\end{array}$ & $\begin{array}{l}-0.088^{* * *} \\
(0.006)\end{array}$ & $\begin{array}{l}-0.050 \\
(0.157)\end{array}$ & $\begin{array}{l}-0.051^{* * *} \\
(0.005)\end{array}$ & $\begin{array}{c}0.003 \\
(0.935)\end{array}$ & $\begin{array}{c}0.005 \\
(0.789)\end{array}$ & $\begin{array}{l}-0.157^{* *} \\
(0.019)\end{array}$ \\
\hline Math z-score & $\begin{array}{l}-0.021 \\
(0.399) \\
\end{array}$ & $\begin{array}{l}-0.058^{\star *} \\
(0.045) \\
\end{array}$ & $\begin{array}{l}-0.062^{\star *} \\
(0.037)\end{array}$ & $\begin{array}{c}0.019 \\
(0.346) \\
\end{array}$ & $\begin{array}{l}-0.029 \\
(0.324) \\
\end{array}$ & $\begin{array}{l}-0.015 \\
(0.400) \\
\end{array}$ & $\begin{array}{l}-0.104 \\
(0.138)\end{array}$ \\
\hline $\begin{array}{l}\text { Number of } \\
\text { observations }\end{array}$ & 872 & 872 & 872 & 872 & 872 & 872 & 872 \\
\hline R-squared & 0.055 & 0.123 & 0.141 & 0.074 & 0.096 & 0.011 & 0.156 \\
\hline
\end{tabular}

Note: The table reports the estimates for the individual fixed effects model, ${ }^{*} p<0.1^{* *} p<0.05^{* * *} p<0.1$. All controls were included as reported. 


\section{Appendix}

Table A.1. Consumption of cigarettes, alcohol and drugs

\begin{tabular}{|c|c|c|c|c|}
\hline \multirow{3}{*}{\begin{tabular}{|l} 
\\
Alcohol consumption
\end{tabular}} & \multicolumn{2}{|c|}{ Age 15} & \multicolumn{2}{|c|}{ Age 19} \\
\hline & $\%$ & $\mathbf{n}$ & $\%$ & $\mathbf{n}$ \\
\hline & & & & \\
\hline \multicolumn{5}{|c|}{ How often do you drink alcohol? } \\
\hline Every day & 0.5 & 3 & 0.7 & 4 \\
\hline At least once a week & 1.6 & 10 & 3.0 & 18 \\
\hline At least once a month & 3.6 & 23 & 5.9 & 35 \\
\hline Only on special occasions & 16.2 & 104 & 31.8 & 190 \\
\hline Hardly ever & 13.1 & 84 & 29.1 & 174 \\
\hline I never drink alcohol & 65.1 & 417 & 29.6 & 177 \\
\hline \multicolumn{5}{|c|}{ How much do you usually drink per day? } \\
\hline I never drink alcohol & 69.5 & 417 & 35.5 & 177 \\
\hline 1 cup/glass or less & 18.3 & 152 & 28.8 & 213 \\
\hline 2 cups/glasses & 6.5 & 38 & 13.2 & 76 \\
\hline 3 cups/glasses or more & 5.7 & 34 & 22.6 & 132 \\
\hline \multicolumn{5}{|c|}{ Have you ever been drunk for too much alcohol? } \\
\hline Yes & 11.5 & 68 & 35.2 & 211 \\
\hline No & 88.5 & 522 & 64.8 & 388 \\
\hline \multicolumn{5}{|l|}{ Cigarettes consumption } \\
\hline \multicolumn{5}{|c|}{ How old were you when you tried a cigarette for the first time? } \\
\hline Average age & NA & & 16.0 & \\
\hline \multicolumn{5}{|c|}{ How often do you smoke cigarettes now? } \\
\hline Every day & 0.6 & 4 & 1.0 & 6 \\
\hline At least once a week & 3.0 & 19 & 6.8 & 40 \\
\hline At least once a month & 3.7 & 24 & 12.2 & 72 \\
\hline Hardly ever & 14.0 & 90 & 27.1 & 160 \\
\hline I never smoke cigarettes & 78.7 & 505 & 53.0 & 313 \\
\hline \multicolumn{5}{|c|}{ How many cigarettes do you usually smoke per day? } \\
\hline I never smoke cigarettes & 78.7 & 505 & 67.3 & 313 \\
\hline 1 cigarette or less per day & 18.5 & 119 & 27.1 & 248 \\
\hline 2 to 5 cigarettes per day & 2.3 & 15 & 5.0 & 27 \\
\hline 6 or more per day & 0.5 & 3 & 0.5 & 3 \\
\hline \multicolumn{5}{|l|}{ Drugs consumption } \\
\hline \multicolumn{5}{|l|}{ Have you ever tried drugs? } \\
\hline Yes & 3.1 & 20 & 14.2 & 84 \\
\hline No & 96.7 & 617 & 85.8 & 508 \\
\hline
\end{tabular}


Table A.1. Consumption of cigarettes, alcohol and drugs continued

\begin{tabular}{|c|c|c|c|c|}
\hline & \multicolumn{2}{|c|}{ Age 15} & \multicolumn{2}{|c|}{ Age 19} \\
\hline & $\%$ & $\mathbf{n}$ & $\%$ & $\mathbf{n}$ \\
\hline \multicolumn{5}{|l|}{ Sexual behaviours } \\
\hline \multicolumn{5}{|c|}{ How old were you when you had sex for the first time? } \\
\hline Average age & NA & & & 16.0 \\
\hline \multicolumn{5}{|l|}{ Ever had sex? } \\
\hline Yes & 19.4 & 109 & 67.2 & 391 \\
\hline No & 80.6 & 453 & 32.8 & 191 \\
\hline \multicolumn{5}{|c|}{ Used condom in last sexual relation } \\
\hline Yes & 12.6 & 71 & 40.5 & 236 \\
\hline No & 6.8 & 38 & 26.5 & 155 \\
\hline Never had sex & 80.6 & 453 & 32.8 & 191 \\
\hline \multicolumn{5}{|c|}{ Criminal behaviours } \\
\hline \multicolumn{5}{|c|}{ During the last 30 days, on how many days did you carry a weapon? } \\
\hline Never & 91.9 & 588 & 3.2 & 567 \\
\hline 1 day & 5.6 & 36 & 0.7 & 19 \\
\hline 2 to 3 days & 0.8 & 5 & 1.5 & 4 \\
\hline More than 4 days & 1.7 & 11 & 94.7 & 9 \\
\hline \multicolumn{5}{|c|}{ Have you ever been member of a gang? } \\
\hline Yes & NA & & 5.5 & 33 \\
\hline No & NA & & 94.5 & 565 \\
\hline \multicolumn{5}{|c|}{ Have you ever been arrested by the police for illegal behaviour? } \\
\hline Yes & NA & & 5.8 & 35 \\
\hline No & NA & & 94.2 & 567 \\
\hline \multicolumn{5}{|c|}{$\begin{array}{l}\text { Have you ever been sentenced to spend time in a corrections } \\
\text { institution? }\end{array}$} \\
\hline Yes & NA & & 6.7 & 10 \\
\hline No & NA & & 93.4 & 591 \\
\hline
\end{tabular}


Table A.2. Consumption of cigarettes, alcohol and drugs at age 19 by gender and location

\begin{tabular}{|c|c|c|c|c|c|c|c|c|c|c|}
\hline & \multicolumn{2}{|c|}{ Female } & \multicolumn{2}{|c|}{ Male } & & \multicolumn{2}{|c|}{ Urban } & \multicolumn{2}{|c|}{ Rural } & \multirow[b]{2}{*}{ test } \\
\hline & $\%$ & $\mathbf{n}$ & $\%$ & $\mathbf{n}$ & test & $\%$ & $\mathbf{n}$ & $\%$ & $\mathbf{n}$ & \\
\hline \multicolumn{11}{|l|}{ Alcohol consumption } \\
\hline \multicolumn{11}{|c|}{ How often do you drink alcohol? } \\
\hline Every day & 0.4 & 1 & 0.7 & 2 & -0.3 & 0.5 & 2 & 0.7 & 1 & -0.3 \\
\hline At least once a week & 0.8 & 2 & 5.3 & 16 & $-4.5^{\star \star \star}$ & 3.9 & 17 & 0.7 & 1 & $3.1^{*}$ \\
\hline At least once a month & 3.3 & 9 & 7.9 & 24 & $-4.6^{* *}$ & 5.7 & 25 & 5.8 & 8 & -0.1 \\
\hline Only on special occasions & 30.6 & 83 & 32.9 & 100 & -2.3 & 33.5 & 148 & 26.8 & 37 & 6.7 \\
\hline Hardly ever & 24 & 65 & 34.5 & 105 & $-10.55^{\star * *}$ & 30.8 & 136 & 25.4 & 35 & 5.4 \\
\hline I never drink alcohol & 41 & 111 & 18.8 & 57 & $22.21^{\text {***}}$ & 25.8 & 114 & 40.6 & 56 & $-14.8^{\star \star \star}$ \\
\hline \multicolumn{11}{|c|}{ How much do you usually drink per day? } \\
\hline I never drink alcohol & 41 & 111 & 18.8 & 57 & $22.21^{\star \star \star}$ & 31.2 & 114 & 46.3 & 56 & $-14.8^{* * *}$ \\
\hline 1 cup/glass or less & 38.4 & 104 & 32.9 & 100 & 5.48 & 29.5 & 160 & 27.2 & 46 & 2.87 \\
\hline 2 cups/glasses & 8.9 & 24 & 16.5 & 50 & $-7.59^{* * *}$ & 14.2 & 60 & 10.3 & 14 & 3.43 \\
\hline 3 cups/glasses or more & 11.8 & 32 & 31.9 & 97 & $-20.10^{\star \star *}$ & 25.1 & 108 & 16.2 & 22 & $8.49^{\star \star}$ \\
\hline \multicolumn{11}{|c|}{ Have you ever been drunk for too much alcohol? } \\
\hline Yes & 22.4 & 60 & 44.4 & 134 & $-22.0^{\star \star \star}$ & 37.7 & 165 & 22.6 & 31 & $15.0^{\star * \star}$ \\
\hline No & 77.6 & 208 & 55.6 & 168 & & 62.3 & 273 & 77.4 & 106 & \\
\hline
\end{tabular}

\section{Cigarettes consumption}

How old were you when you tried a cigarette for the first time?

Average age

16.1

16

How often do you smoke cigarettes now?

Every day

At least once a week

At least once a month

Hardly ever

I never smoke cigarettes

How many cigarettes do you usually smoke per day?

I never smoke cigarettes

1 cigarette or less per day

2 to 5 cigarettes per day

6 or more per day

\section{Drugs consumption}

Have you ever tried drugs?

Yes

No

Sexual behaviours

How old were you when you had sex for the first time?

Average age

Ever had sex?

Yes

No

Used condom in last sexual relation

Yes

No

Never had sex

\begin{tabular}{|c|c|c|c|c|c|c|c|c|c|}
\hline & 16.1 & & 16 & & & 14.1 & & 16.5 & \\
\hline 0.7 & 2 & 1.3 & 4 & -0.6 & 1.4 & 6 & 0 & 0 & 1.4 \\
\hline 2.6 & 7 & 10.7 & 32 & $-8.1^{\text {*** }}$ & 7.5 & 33 & 5.1 & 7 & 2.4 \\
\hline 4.4 & 12 & 18.4 & 55 & -14.0 *** & 11.6 & 51 & 11.7 & 16 & 0 \\
\hline 18.8 & 51 & 35.1 & 105 & $-16.3^{\star \star \star}$ & 27.2 & 119 & 28.5 & 39 & -1.3 \\
\hline 73.4 & 199 & 34.5 & 103 & $39.0^{* * *}$ & 52.3 & 229 & 54.7 & 75 & -2.5 \\
\hline 73.4 & 199 & 34.4 & 103 & $39.0^{\star * *}$ & 52.3 & 229 & 54.7 & 75 & -2.5 \\
\hline 25.1 & 68 & 57.5 & 172 & $-32.4^{* * *}$ & 42 & 184 & 42.3 & 58 & -0.3 \\
\hline 1.5 & 4 & 7 & 21 & $-5.6^{* * *}$ & 5.3 & 23 & 2.2 & 3 & 3.6 \\
\hline 0 & 0 & 1 & 3 & $-1.0^{*}$ & 0.5 & 2 & 0.7 & 1 & -0.3 \\
\hline 7.6 & 20 & 18.8 & 57 & $-11.23^{\star \star *}$ & 14 & 61 & 12.4 & 17 & 1.6 \\
\hline 92.4 & 244 & 81.2 & 246 & & 86 & 374 & 87.6 & 120 & \\
\hline
\end{tabular}

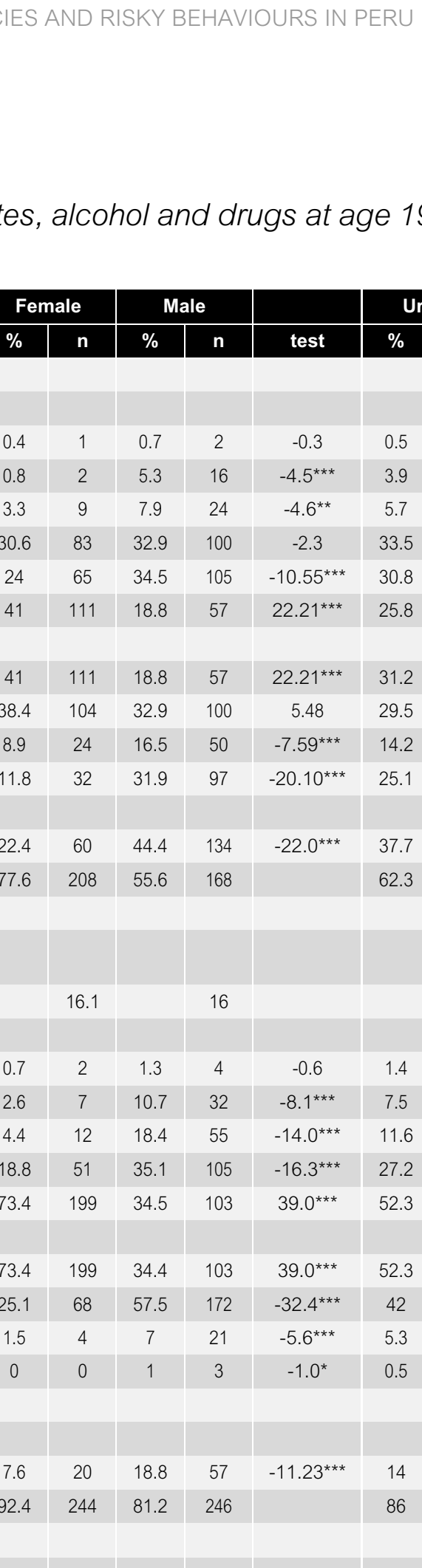


Table A.2. Consumption of cigarettes, alcohol and drugs at age 19 by gender and location continued

\begin{tabular}{|c|c|c|c|c|c|c|c|c|c|c|}
\hline & \multicolumn{2}{|c|}{ Female } & \multicolumn{2}{|c|}{ Male } & \multirow[b]{2}{*}{ test } & \multicolumn{2}{|c|}{ Urban } & \multicolumn{2}{|c|}{ Rural } & \multirow[b]{2}{*}{ test } \\
\hline & $\%$ & $\mathbf{n}$ & $\%$ & $\mathbf{n}$ & & $\%$ & $\mathbf{n}$ & $\%$ & $\mathbf{n}$ & \\
\hline \multicolumn{11}{|c|}{ Criminal behaviours } \\
\hline \multicolumn{11}{|c|}{$\begin{array}{l}\text { During the last } 30 \text { days, on how many days did you } \\
\text { carry a weapon? }\end{array}$} \\
\hline Never & 96 & 262 & 93.7 & 284 & 2.2 & 95.3 & 422 & 93.5 & 129 & 1.8 \\
\hline 1 day & 2.2 & 6 & 4 & 12 & -1.8 & 3.2 & 14 & 2.9 & 4 & 0.3 \\
\hline 2 to 3 days & 0.8 & 2 & 0.7 & 2 & 0.1 & 0.5 & 2 & 1.5 & 2 & -1 \\
\hline More than 4 days & 1.1 & 3 & 1.7 & 5 & 0.6 & 1.1 & 5 & 2.2 & 3 & -1 \\
\hline \multicolumn{11}{|c|}{ Have you ever been member of a gang? } \\
\hline Yes & 2.9 & 8 & 7.6 & 23 & $-4.7^{\star *}$ & 5.9 & 26 & 3.6 & 5 & 2.3 \\
\hline No & 97.1 & 264 & 92.4 & 280 & & 94.1 & 416 & 96.4 & 133 & \\
\hline \multicolumn{11}{|c|}{$\begin{array}{l}\text { Have you ever been arrested by the police for illegal } \\
\text { behaviour? }\end{array}$} \\
\hline Yes & 2.6 & 7 & 8.2 & 25 & $-5.6^{* * *}$ & 5.4 & 24 & 5.8 & 8 & -0.4 \\
\hline No & 97.4 & 267 & 91.8 & 280 & & 94.6 & 421 & 94.2 & 131 & \\
\hline \multicolumn{11}{|c|}{$\begin{array}{l}\text { Have you ever been sentenced to spend time in a } \\
\text { corrections institution? }\end{array}$} \\
\hline Yes & 4 & 11 & 8.5 & 26 & $-4.5^{\star *}$ & 5.9 & 26 & 7.9 & 11 & -2.1 \\
\hline No & 96 & 262 & 91.5 & 279 & & 94.1 & 418 & 92.1 & 128 & \\
\hline
\end{tabular}




\section{Psychosocial Competencies and Risky Behaviours in Peru}

There is a growing concern about the prevalence of risky behaviours among young people, which ultimately lead to worse outcomes later in life, including lower salaries and worse socio-economic and life outcomes. On the other hand, there is little evidence about the prevalence of these behaviours and their determinants in the context of developing countries.

Our aim is to try to fill this gap, using unique individual-level panel data from Peru, following a cohort of about 700 children for more than a decade between the ages of 8 and 19. More specifically, the aim of this study is to get a better understanding of the link between psychosocial competencies related to the concepts of self-esteem, self-efficacy and aspirations, and risky behaviours at a crucial period of transition between adolescence and early adulthood.

- We document a high prevalence of risky behaviours, with one in two individuals engaging in at least one risky activity by the age of 19, and a dramatic increase between ages 15 and 19.

- Our analysis of the predictors of risky behaviours identifies a group of adolescents vulnerable to engaging in risky behaviours. This is particular relevant for boys living in urban areas who have grown up in single-parent households with a large number of siblings.

- Most importantly, we find a negative correlation (robust to a number of specifications) between early self-esteem (measured at the ages of 12 and 15) and later risky behaviours. Further, aspiring to higher education at the age of 15 is correlated with a lower probability of drinking alcohol and of engaging in criminal behaviours at the age of 19. Similarly, such aspirations protect girls from risky sexual behaviours.

Although the present analysis is not sufficient to claim any causal relation between socio-emotional competencies and risky behaviours, our results suggest that psychosocial competencies, and self-esteem and high aspirations in particular, might play a role in reducing risky behaviours. Policies aimed at promoting soft skills during childhood and adoles ᄀcence constitute an important mechanism for reducing risky and criminal activities among young people. To our knowledge this evidence is unique in the developing-countries context.

\section{恔 Young Lives}

An International Study of Childhood Poverty

About Young Lives

Young Lives is an international study of childhood poverty, involving 12,000 children in 4 countries over 15 years. It is led by a team in the Department of International Development at the University of Oxford in association with research and policy partners in the 4 study countries: Ethiopia, India, Peru and Vietnam.

Through researching different aspects of children's lives, we seek to improve policies and programmes for children.

\section{Young Lives Partners}

Young Lives is coordinated by a small team based at the University of Oxford, led by Professor Jo Boyden.

- Ethiopian Development Research Institute, Ethiopia

- Pankhurst Development Research and Consulting plc, Ethiopia

- Centre for Economic and Social Studies, Hyderabad, India

- Save the Children India

- Sri Padmavathi Mahila Visvavidyalayam (Women's University), Andhra Pradesh, India

- Grupo de Análisis para el Desarollo (GRADE), Peru

- Instituto de Investigación Nutricional, Peru

- Centre for Analysis and Forecasting, Vietnamese Academy of Social Sciences, Vietnam

- General Statistics Office, Vietnam

- Oxford Department of International Development, University of Oxford, UK

Contact:

Young Lives

Oxford Department of

International Development,

University of Oxford,

3 Mansfield Road,

Oxford OX1 3TB, UK

Tel: +44 (0)1865 281751

Email: younglives@younglives.org.uk Website: www.younglives.org.uk 